\title{
NITRIC OXIDE AND SYNAPTIC FUNCTION
}

\author{
Erin M. Schuman* and Daniel V. Madison \\ Dept. of Molecular and Cellular Physiology, Stanford University Medical Center, \\ Stanford, California 94303; * present address: Division of Biology, California \\ Institute of Technology, Pasadena, California 91125 \\ KEY WORDS: plasticity, long-term potentiation, long-term depression, NMDA receptor, \\ hippocampus
}

\section{INTRODUCTION}

The free radical gas nitric oxide (NO) is a recently identified neuronal messenger that carries out diverse signaling tasks in both the central and peripheral nervous systems. Whereas most neurotransmitters are packaged in synaptic vesicles and secreted in a $\mathrm{Ca}^{2+}$-dependent manner from specialized nerve endings, NO is an unconventional transmitter which is not packaged in vesicles, but rather diffuses from its site of production in the absence of any specialized release machinery. The lack of a requirement for release apparatus raises the possibility that NO can be released from both pre- and postsynaptic neuronal elements. In addition, because NO is gaseous and extremely membrane permeant, it can bypass normal signal transduction routes involving interactions with synaptic membrane receptors. Although the targets of NO have not yet been completely described, it is known that NO can bind to the iron contained in heme groups, leading to conformational changes in associated proteins, such as guanylyl cyclase.

\section{NO as an Intercellular Signaling Molecule}

The idea that NO may participate in modulating neuronal function originally arose from the discovery that it is an important intercellular signal that maintains vascular tone and resistance. It had long been known that acetylcholine (Ach), as well as many other neurotransmitters and neuromodulators, when applied to arteries or veins was capable of producing relaxations of the smooth muscle. In 1980, Furchgott \& Zawadski reported that the ACh-induced 
relaxation of rabbit aorta required the presence of endothelial cells. In an elegant series of bioassays, endothelial cells were removed from the intimal strip of rabbit aorta, and no relaxation could be elicited. The relaxation of the muscle was then restored by the addition of exogenous endothelial cells. A diffusible factor produced in endothelial cells, endothelial-derived relaxing factor (EDRF), was proposed to account for the observed smooth muscle relaxation. Further studies showed that the relaxation produced by $\mathrm{ACh}$ and other agents was $\mathrm{Ca}^{2+}$-dependent (Griffith et al 1986). In addition, the relaxation was thought to be mediated by rises in cGMP that were shown to occur in the muscle but not in the endothelial cells (Rapoport et al 1983). It was also known that several nitrovasodilators (agents that generate NO, e.g. glyceryl trinitrate and sodium nitroprusside) did not require the presence of endothelial cells to elicit relaxation. Thus, it was proposed that EDRF is NO, based on the following observed similarities of NO and EDRF: both agents are extremely labile (half-life $=4-6 \mathrm{~s}$ ), the relaxations induced by both substances are blocked by hemoglobin (which binds NO) or by generators of $\mathrm{O}_{2}^{-}$, and the effects of both NO and EDRF are enhanced by superoxide dismutase, which scavenges superoxide ions. In 1987, two groups (Ignarro et al 1987, Palmer et al 1987) directly demonstrated that the vascular endothelium actually releases NO in quantities sufficient to account for the biological activity of EDRF.

Since this initial discovery, NO has been implicated in several other systems, including macrophage cytotoxicity (Marletta 1989), nonadrenergic noncholinergic intestinal relaxation (Desai et al 1991), penile erection (Rajfer et al 1992), neurotoxicity (Dawson et al 1991b), and plasticity in the hippocampus (Bohme et al 1991, O'Dell et al 1991, Schuman \& Madison 1991, Haley et al 1992) and cerebellum (Crepel \& Jaillard 1990, Shibuki \& Okada 1990). The first demonstration of NO acting as a neuronal messenger came from studies in cerebellar granule cells by Garthwaite and colleagues (1988). These investigators demonstrated that the application of NMDA to granule cells resulted in rises in cGMP levels that were blocked by both NO synthase (NOS) inhibitors and hemoglobin, suggesting that NO was functioning as an intercellular messenger. These studies drew a significant amount of attention to the signal transduction pathway involving NMDA receptors, NOS, and guanylyl cyclase, and no doubt served as an impetus to many future inquiries, in particular those regarding the role of $\mathrm{NO}$ in synaptic plasticity. Although NO has recently been shown to function in a wide variety of central and peripheral processes, this paper is limited to a brief review of NO and NO synthase as well as a discussion of NO's role in the modulation of synaptic function in the following areas: NMDA receptor currents, neurotoxicity, secretion, long-term depression and potentiation, and animal learning. 


\section{NITRIC OXIDE AND NITRIC OXIDE SYNTHASES}

\section{NOS Isoforms}

Nitric oxide is produced by an NO synthase (NOS). To date, several different nitric oxide synthases have been identified: one or more inducible NOSs present in macrophages, neutrophils, hepatocytes, and possibly glial cells, and at least two different constitutive forms present in endothelial cells and neurons. Four distinct isoforms of NOS have been cloned thus far: a brain NOS (Bredt et al 1991c), an endothelial NOS (Lamas et al 1992, Marsden et al 1992, Sessa et al 1992), a macrophage NOS (Lowenstein et al 1992, Xie et al 1992), and a hepatocyte NOS (Geller et al 1993). The different classes of cloned enzymes share about $50 \%$ identity in their amino acid sequences. All forms of NOS characterized thus far require several electron donors [flavin adeninedinucleotide (FAD), flavin mononucleotide (FMN), nicotinamide adenine dinucleotide phosphate (NADPH), and tetrahydrobiopterin] and produce NO by oxidizing one of the terminal guanidino nitrogens of L-arginine, resulting in the stoichiometric production of L-citrulline (Figure 1).

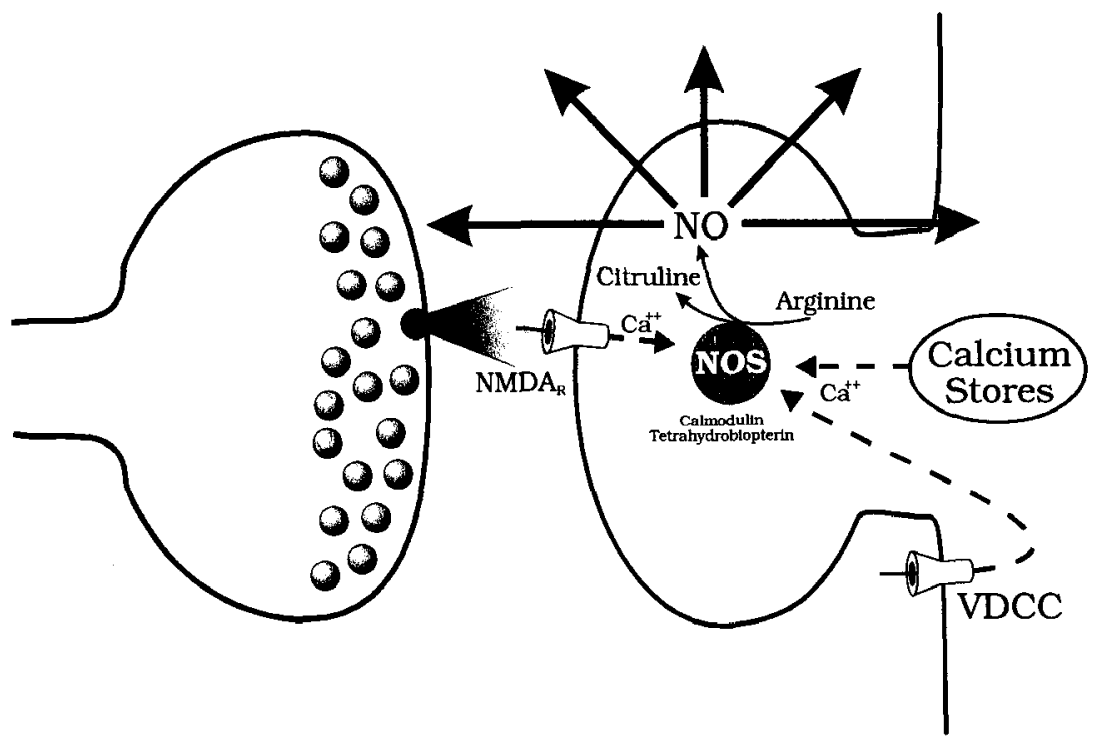

Figure 1 Diagram of NO production at synapses. The calcium signal derived from the NMDA receptor-channel, voltage-dependent $\mathrm{Ca}^{2+}$ channels (VDCC), or intracellular stores binds calmodulin and activates the nitric oxide synthase (NOS). Activated NOS produces NO from L-arginine. NO can then diffuse from its site of production to influence all nearby synapses. 
The amino acid sequence of a brain NOS, originally purified from rat cerebellum (Bredt \& Snyder 1990), encodes a protein of $160 \mathrm{kD}$ that contains several recognition sites for required cofactors, including a basic amphipathic $\alpha$ helix calmodulin-binding consensus site, a cAMP-dependent protein kinase phosphorylation consensus sequence, a NADPH-binding domain, and potential binding sites for FMN and FAD (Bredt et al 1991a,c). The C-terminal half of NOS shows substantial homology to rat cytochrome P-450 reductase and sulphite reductase (Bredt et al 1991c), which also contain binding sites for NADPH, FMN, and FAD. The full-length cDNA was inserted into an expression vector and transfected into human kidney 293 cells. The expressed NOS protein exhibited catalytic activity with properties corresponding to those observed with the native NOS in cerebellum, namely a dependence on $\mathrm{Ca}^{2+}$ and NADPH and inhibition by calmodulin antagonists.

A family of endothelial NOSs has also been cloned, including a bovine endothelial NOS (Lamas et al 1992, Sessa et al 1992) and a human NOS (Janssens et al 1992, Marsden et al 1992). The deduced amino acid sequences of both the bovine and human endothelial NOSs encode a protein of approximate molecular mass $133 \mathrm{kDa}$, consistent with observed molecular weight $(135,000)$ of the purified protein (Pollock et al 1991). The sequences of the two isoforms are highly homologous with one another (90\%) and exhibit 50 and $60 \%$ homology with the cloned macrophage and brain NOS, respectively. Like the brain NOS, the endothelial NOS also contains binding regions for calmodulin, NADPH, FMN, and FAD, as well as a consensus sequence for phosphorylation by cAMP-dependent protein kinase. Interestingly, the endothelial NOS sequence also contains a consensus sequence for myristylation at the amino terminus; as discussed below, this may account for particulate localization of the endothelial NOS. The cloned cDNAs have also been inserted into expression vectors and transiently expressed in COS cells (Lamas et al 1992, Sessa et al 1992) or NIH3T3 cells (Janssens et al 1992). The transfected cells exhibited $\mathrm{Ca}^{2+}$-dependent conversion of L-arginine to NO and citrulline that was sensitive to the NOS inhibitor L-NARG or L-NAME.

Two apparently distinct isoforms of inducible NOS have been cloned: one from macrophages (Lowenstein et al 1992, Lyons et al 1992, Xie et al 1992) and one from human hepatocytes (Geller et al 1993). These two inducible NOSs possess $80 \%$ amino acid sequence homology. The sequences of both forms encode smaller proteins than the brain NOS; the approximate molecular mass is $130 \mathrm{kD}$. As in other NOS isoforms, recognitions sites for FMN, FAD, and NADPH are present. Although the activity of the macrophage NOS has been observed to be largely $\mathrm{Ca}^{2+}$ - and calmodulin-independent, the enzyme contains a recognition site for calmodulin binding. In human 293 kidney cells transfected with the macrophage cDNA, the expression and activity of 
macrophage NOS was markedly enhanced by treatment with lipopolysaccharide but was not affected by $\mathrm{Ca}^{2+}$ chelators (Lowenstein et al 1992). The hepatocyte NOS also contains a calmodulin-binding domain. In contrast to the macrophage NOS, however, the cloned hepatocyte NOS expressed in human 293 kidney cells displayed an activity that was significantly attenuated by both $\mathrm{Ca}^{2+}$ chelation and calmodulin antagonists (Geller et al 1993). Further studies are obviously needed to explore the potential $\mathrm{Ca}^{2+}$ - and calmodulindependence of inducible NOS activity and to determine whether these two cofactors might also play a role in modulating the expression of inducible NOS.

\section{Enzyme Activation}

The expression of the inducible NOS requires protein synthesis and is initiated by various cytokines and microbial products (Hibbs et al 1987, Stuehr \& Marletta 1987). Following induction, NO is produced in large quantities (nanomoles) for several hours. In contrast, the constitutive NOS found in blood vessels and in brain remains active for relatively short periods of time and produces smaller quantities of NO (picomoles). This NOS is activated by $\mathrm{Ca}^{2+}$ that is bound to calmodulin (Knowles et al 1989, Bredt \& Snyder 1990). In the periphery, the primary source of $\mathrm{Ca}^{2+}$ may be agonist-induced phosphoinositide (PI) hydrolysis resulting in inositol-triphosphate-mediated release of $\mathrm{Ca}^{2+}$ from intracellular stores. In the brain, the flux of $\mathrm{Ca}^{2+}$ through the NMDA receptor-channel has been implicated as the source of $\mathrm{Ca}^{2+}$ in many systems, although it seems possible that influx of $\mathrm{Ca}^{2+}$ via voltage-sensitive $\mathrm{Ca}^{2+}$ channels or release of $\mathrm{Ca}^{2+}$ from intracellular stores via neurotransmitter-induced PI hydrolysis (e.g. the metabotropic glutamate receptor) may also activate the brain NOS (Figure 1).

\section{Localization}

The purification and cloning of the various NOS isozymes has prompted the development of antibodies and antisense oligonucleotides that in turn have permitted immunohistochemical mapping of NOS and localization of the NOS mRNA by in situ hybridization. In addition, the histochemical marker nitrotetrazolium blue (NTB) reacts with NOS-containing neurons (Dawson et al 1991a, Hope et al 1991). This reaction is accounted for by the redox activity of NOS, which reduces nitrotetrazolium blue to NADPH diaphorase. In situ hybridization (Bredt et al 1991b) for the brain NOS (originally purified from cerebellum) reveals a high density of silver grains in the cerebellum, olfactory bulb, and the pedunculopontine tegmental nucleus. In the pedunculopontine tegmental area NOS-positive cells also contain choline acetyltransferase (Dawson et al 1991a). Strong hybridization is also apparent in the hippocampus (dentate gyrus), supraoptic nucleus, and superior and inferior colliculus. 


\section{SCHUMAN \& MADISON}

Isolated NOS-containing neurons have been observed in the cerebral cortex and the corpus striatum (Bredt et al 1991, Dawson et al 1991). These cells also stain positive for somatostatin and neuropeptide Y (Vincent et al 1983, Dawson et al 1991).

A matter of considerable debate concerns the localization of NOS in the hippocampus and the cerebellum, two areas where NO has been implicated in synaptic plasticity. Several studies (Bredt et al 1990, 1991b; Valtschanoff et al 1993) have noted a lack of NOS immunoreactivity in rat CAl pyramidal neurons, the site where $\mathrm{NO}$ has been proposed to be produced during the induction of long-term potentiation (O'Dell et al 1991, Schuman \& Madison 1991). However, recent studies have reported that CAl pyramidal neurons of the hippocampus stain for NADPH diaphorase (Wallace \& Fredens 1992) or an NOS antibody (Schweizer et al 1993). Likewise, staining for NOS and NADPH diaphorase has been observed in cerebellar granule cells and basket cells, but has not been detected in Purkinje cells, where modification of postsynaptic glutamate receptors has been proposed to underlie long-term depression (LTD). This has led to the suggestion that during LTD, NO is generated in other NOS-containing neurons in the cerebellar circuit. Of course, the possibility remains that Purkinje cells express lower levels of NOS, which have not been detected; alternatively, it is also possible that a different isoform of brain NOS may be present in Purkinje neurons and CA1 pyramidal cells.

\section{Regulation}

The NOS isoforms may be regulated by several posttranslational forms of modification, including phosphorylation and myristylation. Purified brain NOS can be phosphorylated by cAMP-dependent protein kinase (Brune \& Lapetina 1991, Bredt et al 1992), protein kinase C (Nakane et al 1991, Bredt et al 1992), and $\mathrm{Ca}^{2+} /$ calmodulin-dependent protein kinase II (Nakane et al 1991, Bredt et al 1992, Schmidt et al 1992). The phosphorylation by all three kinases occurs primarily on serine residues; each kinase predominantly phosphorylates a distinct residue (Bredt et al 1992). The effects of phosphorylation on NOS activity appear to be controversial: PKC has been reported to both increase (Nakane et al 1991) and decrease (Bredt et al 1992) NOS activity. cAMP-dependent protein kinase has been reported to have no effect on NOS activity (Brune \& Lapetina 1991, Bredt et al 1992). Phosphorylation by $\mathrm{Ca}^{2+} /$ calmodulin-dependent protein kinase has been reported to decrease NOS activity (Nakane et al 1991, Schmidt et al 1992) or to have no effect (Bredt et al 1992). The apparent discrepancies between these findings may result from differing basal conditions used in the assays, including the presence or absence of $\mathrm{Ca}^{2+}$ and/or calmodulin in the reaction mixtures. More studies are needed to clarify the effects of phosphorylation on physiological NOS 
activity and to explore the possibility that NO may in turn modulate the activity of protein kinases.

Evidence indicates that the endothelial isoform of NOS can be myristylated (Pollock et al 1992). Co- or posttranslational modification of proteins by myristylation is thought to confer membrane association. Whereas the macrophage and brain forms of NOS appear to be located primarily in soluble fractions, the endothelial form of NOS is located predominantly in particulate fractions (Forstermann et al 1991). None of the cloned NOS isoforms appear to have hydrophobic signal sequences that would correspond to membraneassociated regions. However, at the amino terminal portion, the endothelial NOS contains a consensus sequence for $\mathrm{N}$-myristyl transferase, an enzyme that catalyzes myristylation (Kaplan et al 1988). The brain and macrophage forms of NOS lack this consensus sequence (Bredt et al 1991c, Xie et al 1992). Incubation of bovine endothelial cells with $\left[{ }^{3} \mathrm{H}\right]$ myristate results in the incorporation of myristate into the endothelial NOS (Pollock et al 1992). Thus, the fatty acid acylation of the endothelial NOS may serve as a membrane anchor. Site-directed mutagenesis of the N-myristyl transferase consensus sequence is needed to determine whether this type of modification is required for the localization of endothelial NOS to particulate fractions. Since there are a few reports (Forstermann et al 1992, Hiki et al 1992) of insoluble forms of both the macrophage and brain NOS enzymes, it will be interesting to see whether myristylation may also target other forms of NOS to the membrane.

\section{NO Donors, Scavengers and Inhibitors}

A variety of pharmacological tools have been used to elucidate the functions of NO. Many of the classic nitrovasodilators exert their actions by releasing NO. These types of compounds, including sodium nitroprusside, hydroxylamine, isosorbide dinitrate, 3-morpholino-sydnonimine (SIN-1), and S-nitroso-N-penicillamine (SNAP) can been used to assess the sufficiency of NO as a signaling molecule in various systems. These agents release NO by different mechanisms: some compounds that are presumably membrane impermeant, such as SIN-1 and SNAP, release NO in the extrasynaptic space; others, such as hydroxylamine and isosorbide dinitrate, are thought to release NO from intracellular locations, since they likely require cellular enzymes such as catalases and cytochromes to release NO. It is important to note that higher concentrations of NO donors may be needed when working with intact tissue (e.g. brain slices), since it has been shown that the concentrations of donors required to elevate cGMP in slices are orders of magnitude higher than those required to stimulate guanylyl cyclase in broken cell preparations (Southam \& Garthwaite 1991). This observation indicates that intact tissue may possess mechanisms for rapidly inactivating NO.

In addition, several competitive inhibitors of the NOS are available, 
including L-arginine derivatives such as NG-monomethyl-L-arginine (LNMMA, L-Me-Arg), NG-nitro-L-arginine (NARG), and L-nitro arginine methyl ester (L-NAME). Many of these compounds also have D-isomeric forms that do not inhibit NOS and thus serve as useful controls. Another compound that has proven to be particularly useful in blocking NO's action is hemoglobin. NO and other putative messengers, such as carbon monoxide (CO), bind avidly to the iron in the heme group of hemoglobin. Because hemoglobin is a large protein, it is unlikely to cross cellular membranes. Thus, when applied extracellularly hemoglobin may provide information regarding NO's function as an intercellular, rather than intracellular, messenger.

\section{NO Effectors}

The major effector of NO identified in many tissues is a soluble guanylyl cyclase (Arnold et al 1977, Miki et al 1977, Murad et al 1978). The soluble guanylyl cyclase is a heterodimer that contains a heme, the region responsible for NO activation of the cyclase. When $\mathrm{NO}$ binds to $\mathrm{Fe}^{2+}$ in the porphyrin ring of heme, this interaction pulls the $\mathrm{Fe}^{2+}$ out of the plane of the porphyrin ring, resulting in a conformational change and activation of the guanylyl cyclase (Wolin et al 1982). The resulting rises in cGMP levels can then affect ion channel or phosphodiesterase activity, or activate a cGMP-dependent protein kinase. In smooth muscle cells, the NO-induced rises in cGMP may activate a cGMP-dependent protein kinase that is ultimately responsible for muscle relaxation (Rapoport et al 1983). Alternatively, cGMP has been observed to decrease intracellular $\mathrm{Ca}^{2+}$ levels, which may also contribute to relaxation (Rashatwar et al 1987). Carbon monoxide, also recently identified as a potential messenger molecule (Verma et al 1993), also activates guanylyl cyclase (Brune \& Ullrich 1987), although much less potently than NO (Furchgott \& Jothianandan 1991).

NO can also combine with superoxide anions to form peroxynitrite. Peroxynitrite ultimately decomposes to hydroxide and $\mathrm{NO}_{2}$ free radicals, which are believed to be the bactericidal and tumoricidal effectors of activated macrophages and neutrophils (Beckman et al 1990). NO may also exert its cytotoxic effects by binding to the iron-sulphur centers of enzymes involved in mitochondrial transport electron chain (Granger et al 1980), the citric acid cycle (Drapier \& Hibbs 1986), and DNA synthesis (Nakaki et al 1990). If the inducible NOS exists in noncultured astrocytes, then the NO generated by the inducible NOS may also contribute to the neuronal damage associated with cerebral ischemia (Nowicki et al 1991).

NO may also produce its effects by stimulating the ADP-ribosylation of proteins (Brune \& Lapetina 1989). ADP-ribosylation involves the covalent attachment of ADP-ribose to substrate proteins; this reaction is usually catalyzed by cellular ADP-ribosyltransferases. Brune \& Lapetina (1989) 
demonstrated that sodium nitroprusside induced the ADP-ribosylation of a $39-\mathrm{kD}$ protein in platelets. Later studies have identified this $39-\mathrm{kD}$ protein as glyceraldehyde 3' phosphate dehydrogenase (GAPDH) (Dimmeler \& Brune 1992, Kots et al 1992, Zhang \& Snyder 1992) and have indicated that NO promotes the auto-ADP-ribosylation of GAPDH, rather than activating a distinct ADP-ribosyltransferase. NO first stimulates the S-nitrosylation of a cysteine residue adjacent to the NAD-binding site in the catalytic region of GAPDH (Molina y Vedia et al 1992). The subsequent auto-ADP-ribosylation of GAPDH is thought to occur on this S-nitrosylated cysteine residue (Dimmeler \& Brune 1992, Zhang \& Snyder 1992). The ADP-ribosylation of GAPDH results in a reduction of the normal dehydrogenase activity of GAPDH (Dimmeler et al 1992, Zhang \& Snyder 1992). However, in addition to stimulating auto-ADP-ribosylation of GAPDH, NO apparently may also modulate the activity of endogenous cellular ADP-ribosyltransferases. Several groups have also described NO-stimulated ADP-ribosylation of distinct neuronal proteins (Williams et al 1992) that lack $\mathrm{NAD}^{+}$-binding domains, including transducin (Ehret-Hilberer et al 1992) and other putative GTP-binding proteins (Duman et al 1991). The ADP-ribosylation of these proteins has been proposed to be mediated by a distinct ADP-ribosyltransferase. Thus, it appears that NO may stimulate both auto- and ADP-ribosyltransferase-mediated covalent modifications. Future studies should be aimed at identifying additional substrates for NO-stimulated ADP-ribosylation as well as delineating the functional consequences of this form of covalent modification in neurons.

\section{NO AND SYNAPTIC FUNCTION}

\section{$N$-methyl-D-aspartate Receptor-Channel}

One role of NO in the brain may be as a neuromodulatory substance, analogous to some neurotransmitters. One example of NO's modulatory function may be it's reported ability to influence ion currents through the N-methyl-D-aspartate (NMDA) receptor channels. The NMDA receptor-channels are a rather unique class of glutamate receptor channels that usually require depolarization (Mayer \& Westbrook 1987, Nowak et al 1984) to flux $\mathrm{Ca}^{2+}$ (MacDermott et al 1986, Jahr \& Stevens 1987, Ascher \& Nowak 1988). Thus, by modulating current flow through this particular channel, NO could potentially influence many $\mathrm{Ca}^{2+}$-regulated neuronal processes that utilize this receptor, such as synaptic transmission, plasticity, neurotoxicity, and some aspects of development.

Several different NO-donating compounds (sodium nitroprusside, nitroglycerin, S-nitrosocysteine, and SIN-1) have been shown to reduce NMDA 
currents (Lei et al 1992, Manzoni et al 1992a). The use of several different NO donors is important, since it has been shown that sodium nitroprusside can exert effects on NMDA currents that can be reversed by hemoglobin, but are apparently unrelated to NO since these effects are not shared by other NO-donating compounds (East et al 1991, Manzoni et al 1992b). Manzoni et al (1992a) demonstrated that the SIN-1-induced reduction in the NMDA current was accompanied by an attenuation of NMDA-mediated rises in intracellular $\mathrm{Ca}^{2+}$, as revealed by measurements of Fura- 2 fluorescence (see also Hoyt et al 1992). The effects of NO could be blunted by simultaneous application of hemoglobin, and were absent when NO-depleted SIN-1 was applied. On the basis of these results, it was suggested that NO may play a role as a feedback modulator. According to this scheme, when the NMDA receptor is activated the resulting entry of $\mathrm{Ca}^{2+}$ into the cell activates the NO synthase, leading to the reduction of subsequent NMDA currents.

Much has been learned about the possible mechanisms of the observed NO modulation of NMDA currents. Early studies had shown that NMDA currents could be influenced by the redox state of a site on the receptor channel complex (Aizenman et al 1989, 1990; Lazarewicz et al 1989). A pair of closely-spaced cysteine residues thought to reside on the extracellular side of the channel may form a disulfide bond that constitutes the redox site of the NMDA complex. Reducing this site with agents such as dithiothreitol (DTT) increases the current flow through the channel, whereas oxidizing the redox site, by using 5,5-dithio-bis-2-nitrobenzoic acid (DNTB), decreases the current flow (Lei et al 1992). DNTB can reverse the DTT-induced potentiation of current flow, but this reversal can be prevented by treatment with the irreversible sulfhydryl alkylating agent N-ethylmalemide (NEM). Such treatments similarly affect the synaptic currents through the NMDA channels (Tauck 1992).

The effect of NO on NMDA currents appears to be mediated through this redox site. It has been proposed that the free sulfhydryl groups on the NMDA channel complex are oxidized in the presence of NO to form S-nitrosothiols (Lei et al 1992). In support of this idea, after treatment with NO-donating compounds the oxidant DNTB had no further significant effect (Lei et al 1992). The reducing agent DTT could substantially reverse the effects of NO. In addition, the action of nitrogylcerine was blocked by treatment with NEM. Cyclic GMP apparently does not mediate the effect of NO at the redox site, as application of cGMP did not have any effect on the current (East et al 1991, Kiedrowski et al 1992). Indeed, the SIN-1-induced decrease in the NMDA current can still be recorded in isolated outside-out patches of membrane, suggesting that NO's effect is not mediated by a soluble messenger.

Reduction of NMDA currents by NO may have significance for many cellular processes involving the NMDA receptor. However, at present this 
inhibition appears to be essentially a feedback mechanism, since the NMDA receptor must first be activated (to flux $\mathrm{Ca}^{2+}$ that activates the NO synthase) before the currents can be reduced. In light of this consideration, some processes-those that depend on very brief activation of the NMDA receptor-may not be affected by the subsequent inhibition of the NMDA current. An example of such a process may be long-term potentiation (see below), in which NMDA receptors are transiently activated during the induction of LTP, but are not required for the maintenance or expression of LTP. Thus, this feedback inhibitory mechanism may be of more relevance to processes that involve prolonged activation of NMDA receptors, such as neurotoxicities.

\section{Neurotoxicity}

Considerable controversy surrounds the role of NO in various forms of neurotoxicity that possess different etiologies. One possible consequence of the NO-mediated reduction in NMDA currents discussed above could be attenuation of NMDA-mediated neurotoxicity. In addition, it has been known for some time that neurons that stain positive for NADPH diaphorase (and thus presumably contain NOS) are particularly resistant to neurological insults (Ferrante et al 1985, Beal et al 1986, Koh et al 1986, Hyman et al 1992). Conversely, the documented participation of NO in macrophage-mediated cell killing (Hibbs et al 1988) suggests that NO might be involved in promoting glutamate-mediated cell death. The data examining NO's role in glutamateinduced toxicity often lead to different conclusions; some results are consistent with $\mathrm{NO}$ acting as a neuroprotective agent while others suggest that NO is neurotoxic.

Dawson et al (1991b) have shown that inhibition of NO production can have profound effects in preventing glutamate and NMDA-mediated death of cultured cortical neurons. Using a trypan blue exclusion assay, they demonstrated that the application of NOS inhibitors attenuated the neurotoxic effects of glutamate. This inhibition of toxicity could largely be reversed by the application of excess L-arginine. In agreement, Izumi et al (1992) have shown that in hippocampal slices NOS inhibitors can prevent glutamate and NMDAmediated cell death. As in the culture system, this inhibition is reversed by the addition of excess L-arginine. These results suggest that NO promotes and is necessary for glutamate-mediated cell death.

In contrast to the above results, other data show that NO can prevent NMDA-mediated cell death. Lei et al (1992) have shown that application of sodium nitroprusside or nitroglycerine prevents the toxicity of NMDA in cultured cortical neurons. This study showed a parallel reduction in the NMDA current, as well as diminished intracellular $\mathrm{Ca}^{2+}$ levels with NO. These changes were proposed to underlie the observed protective effect of $\mathrm{NO}$ against the NMDA-mediated toxicity. 
Many studies examining the relationship between NO and glutamate/ I!MDA-mediated toxicity have failed to support any role for NO, either protective or toxic. Kiedrowski et al (1991) showed that sodium nitroprusside could prevent toxicity, as in Lei et al (1992). However, it was concluded that the protective effect of sodium nitroprusside was not mediated by NO, since it was not reproduced by another NO donor, SNAP, but could be reproduced by ferricyanide (a ferricyanide group is present in sodium nitroprusside). It should be noted, however, that the results of Lei et al (1992) did not rely entirely upon the use of sodium nitroprusside, but were also obtained with another NO donor, nitroglycerine. In addition, in rats chronically treated with NOS inhibitors, no decrease in NMDA toxicity could be detected (LernerNatoli et al 1992). In other studies NOS inhibitors did not decrease the toxicity caused by glutamate, NMDA, or other agonists in cultures of cerebellar granule cells (Puttfarcken et al 1992), in neurons cultured from whole rat brain (Demerle-Pallardy et al 1991), or in glial free neuronal cultures (Pauwels \& Leysen 1992).

Thus, experimental results support a role for NO in neurotoxicity ranging from protective to no role to toxic. The discrepancies between these studies could potentially arise from several different sources. First, they may simply represent the outcomes of nonstandardization of technique and preparation. Different cell populations may be differentially sensitive to NO. In addition, differing ratios of cell types (neuronal vs glial) in different preparations may contribute to the discrepancies. Also, the methods and durations of applications of NO donors and NOS inhibitors may also be important. Second, there may be multiple pathways that mediate glutamate-induced toxicity. NO may participate in neurotoxicity, but neurodegeneration could still proceed in the absence of NO via a parallel redundant mechanism. Third, NO itself may exert multiple, perhaps opposing actions, depending on the timing or concentration of its application. A more precise definition of the role of NO in cytotoxicity mediated by glutamate or other factors awaits further experiments that consider the above issues. One result that does emerge clearly at this time is that cGMP production stimulated by NO does not appear to play any role in producing toxicity, since direct application of cGMP is not toxic to cells (see Lustig et al 1992).

\section{Secretion}

In several different brain regions NO has been shown to modulate synaptic function by altering the release of neurotransmitter from presynaptic nerve endings. Using a push-pull cannula, Prast and Phillipu (1992) examined the ability of the NO donor SIN-1 to modulate the basal release of acetylcholine in the basal forebrain, an area where NOS-containing neurons are colocalized with choline acetyltransferase (Dawson et al 1991a). Introduction of the NO 
donor SIN-1 into the superfusate induced a near doubling of the basal release of acetylcholine. Superfusion of the tissue with the NOS inhibitor NARG reduced the basal release of acetylcholine by roughly $40 \%$, suggesting that there is continuous NO production that regulates secretion in this system. In hippocampal slices, the NO donor hydroxylamine stimulated the efflux of $\left[{ }^{3} \mathrm{H}\right]$ norepinephrine and $\left[{ }^{14} \mathrm{C}\right]$ acetylcholine (Lonart et al 1992). The hydroxylamine-stimulated release was attenuated by hemoglobin, suggesting that the effect was mediated by NO. Extracellularly applied EGTA also abolished the NO-stimulated release, suggesting that NO exerts its effect by modulating $\mathrm{Ca}^{2+}$-dependent exocytosis.

Two groups have examined the effects of NO on both the basal and evoked release of dopamine from rat striatal slices. Zhu \& Luo (1992) observed that basal dopamine release increased up to $330 \%$ of baseline following the addition of sodium nitroprusside. L-arginine also produced a large enhancement of basal release when added to the bathing medium; this potentiation of release could be blocked by the coadministration of the NOS inhibitor L-Me-Arg. Hanbauer et al (1992) have reported an NMDA-evoked release of $\left[{ }^{3} \mathrm{H}\right]$ dopamine that is sensitive to NOS inhibitors and hemoglobin. Exogenous application of $\mathrm{NO}$ also elicited increases in the basal release of $\left[{ }^{3} \mathrm{H}\right]$ dopamine from primary cultures of ventral mesencephalic neurons.

In addition to several examples of NO-induced stimulation of release, in at least one system NO has also been shown to have an inhibitory influence on secretion. The magnocellular secretory neurons of the paraventricular and supraoptic nuclei in the hypothalamus stain intensely with antibodies to NOS (Bredt et al 1990). The paraventricular nucleus is the major source of the hypophysiotropic factor corticotropin-releasing hormone (CRH) (Kawano et al 1988). L-arginine, NO donors, or NOS inhibitors had no effect on the basal secretion of $\mathrm{CRH}$ in hypothalamic explants, as measured by radioimmunoassay (Costa et al 1993). However, the release of CRH induced by depolarization $\left(40 \mathrm{mM} \mathrm{K}^{+}\right)$or the cytokine interleukin 1B was potently reduced by either $\mathrm{L}$-arginine or an NO donor. The inhibitory effect of L-arginine was blocked when the NOS inhibitor L-Me-Arg or hemoglobin was coincidently applied. These results suggest that NOS activation upon depolarization may function as inhibitory feedback contributing to hypotension by reducing $\mathrm{CRH}$ release.

Thus there are several examples of NO modulating the release of a variety of secretory substances. It appears that in different systems NO is capable of either increasing or decreasing neurotransmitter release. In theory, this bipotential control could be accomplished by NO's acting on different downstream enzymes or secretory targets, or by a common target molecule or enzyme whose modulation state determines whether release will be augmented or depressed. As such, it will be interesting to examine the molecular mechanisms by which NO modulates neurotransmitter release. 
Because previous studies have shown that $\mathrm{NO}$ can modulate $\mathrm{Ca}^{2+}$ influx (Lei et al 1992), it is possible that NO alters presynaptic $\mathrm{Ca}^{2+}$ influx or homeostasis. Alternatively, NO may alter the function of various synaptic vesicle proteins implicated in secretion.

\section{Long-Term Potentiation}

Long-term potentiation (LTP), which has been observed in many brain areas, has proven to be a powerful system for the study of the molecular mechanisms that underlie activity-dependent enhancement of synaptic strength. At the CA1-Schaffer collateral synapses of the hippocampus, LTP occurs when the excitatory synapses are stimulated such that the depolarization of postsynaptic CA1 neurons is coincident with the release of neurotransmitter from the presynaptic CA3 nerve terminals. This is usually accomplished through the delivery of high-frequency stimulation to presynaptic axons $(100 \mathrm{~Hz}$; tetanus) or through the pairing of postsynaptic depolarization produced by current injection with low-frequency stimulation of presynaptic axons (pairing). Most of our understanding of the molecular processes responsible for LTP has to do with those events that underlie the initiation, or induction, of LTP. Studies from several laboratories have highlighted a cascade of postsynaptic events that initiate LTP, including postsynaptic depolarization (Malinow \& Miller 1986), glutamate binding to the NMDA receptor-channel (Collingridge et al 1983), and $\mathrm{Ca}^{2+}$ influx (Lynch et al 1983, Malenka et al 1988). The rise in $\mathrm{Ca}^{2+}$ has been proposed to activate any one or combination of postsynaptically located $\mathrm{Ca}^{2+}$-dependent enzymes, including protein kinase $\mathrm{C}$ (Lovinger et al 1987; Malinow et al 1988, 1989), $\mathrm{Ca}^{2+}$ /calmodulin-dependent protein kinase II (Malenka et al 1989, Malinow et al 1989, Silva et al 1992), calpain (Lynch \& Baudry 1984), phospholipase $A_{2}$ (Williams et al 1989), and NOS (Bohme et al 1991, O'Dell et al 1991, Schuman \& Madison 1991a, Haley et al 1992), all of which have been implicated in LTP to some extent.

In contrast to the possible exclusive role of the postsynaptic neuron in the induction of LTP, several lines of evidence suggest that the presynaptic neuron may also participate in the longer lasting aspects of LTP, known as maintenance and expression. Quantal analyses of synaptic transmission before and after LTP have often concluded that at least part of the increase in synaptic strength observed following LTP induction results from an increase in the release of neurotransmitter (Bekkers \& Stevens 1990, Malinow 1991, Malinow \& Tsien 1990, Kullman \& Nicoll 1992, Malgaroli \& Tsien 1992; but see Foster \& McNaughton 1991, Manabe et al 1992). Thus, LTP is induced postsynaptically but may be expressed, at least in part, presynaptically. This shift of locus requires that the presynaptic cell receive a signal from the postsynaptic cell that indicates that LTP induction is occurring. This postsynaptically generated retrograde signal would then be responsible for bringing 
about increases in neurotransmitter release. An early candidate for this signal was arachidonic acid, generated by a $\mathrm{Ca}^{2+}$-sensitive phospholipase $\mathrm{A}_{2}$. Extracellularly applied inhibitors of $\mathrm{PLA}_{2}$ have been shown to block LTP (Williams et al 1989), and extracellular application of arachidonic acid coupled with weak tetanic stimulation can enhance synaptic transmission (Williams et al 1989), although the onset of this enhancement is much slower than the onset of LTP.

More recently, several labs have queried the possibility that NO may function as retrograde signal in LTP. Given the $\mathrm{Ca}^{2+}$ - and calmodulin-dependence of the brain NOS and the established role of both of these molecules in LTP induction (Madison et al 1991), NO appears at the outset to be particularly well suited to perform the functions of a retrograde signal. In initial experiments we (Schuman \& Madison 1991a) and others (Bohme et al 1991, O'Dell et al 1991, Haley et al 1992) showed that extracellular application of NOS inhibitors prevents tetanus-induced LTP. The inhibition of LTP produced by competitive NOS inhibitors can be reversed by the addition of L-arginine, as would be expected if the actions of the inhibitors are on the NOS. It appears that NO production is necessary only during LTP induction, since NOS inhibitors applied $20-30 \mathrm{~min}$ after high-frequency stimulation do not reverse established LTP (O'Dell et al 1991, Haley et al 1992).

The above experiments utilized extracellular bath application of NOS inhibitors to demonstrate NO's importance in the production of LTP. However, these experiments do not indicate the synaptic site of NO generation. By definition, the retrograde signal must be produced in the postsynaptic neuron. Indeed, this appears to be the case for NO, since NOS inhibitors injected into the postsynaptic neuron will block LTP induced by pairing postsynaptic depolarization with low frequency stimulation of afferents (O'Dell et al 1991, Schuman \& Madison 1991). Injection of the D-isomers of NOS inhibitors has no effect on LTP production. Hemoglobin applied extracellularly also attenuates LTP (Bohme et al 1991, O'Dell et al 1991, Schuman \& Madison 1991, Haley et al 1992), whereas methemoglobin, which has a much lower affinity for NO, has no effect. The reduction of LTP by hemoglobin is consistent with the idea that NO functions as an intercellular signal, traveling from the post- to the presynaptic neuron.

If postsynaptically released NO interacts with the presynaptic terminal to bring about LTP, then the exogenous application of NO coupled with presynaptic activity should be sufficient to induce synaptic potentiation. The ability of NO or NO donors to increase synaptic strength in hippocampal slices has not been readily observed, possibly because of the extreme lability of NO and the difficulty of reaching appropriate concentrations in the depth of the tissue (Southam \& Garthwaite 1991). However, a few groups have had some 
success. Bohme and colleagues (Bohme et al 1991, Bon et al 1992) have shown that extracellular application of two different NO donors, hydroxylamine and sodium nitroprusside, can potentiate synaptic transmission in a manner that occludes normal synaptically-induced LTP. Direct application of NO has also been demonstrated to augment synaptic transmission: in cultured hippocampal neurons NO increases the frequency of spontaneous miniature synaptic events (O'Dell et al 1991). In hippocampal slices bathed in the NMDA receptor antagonist AP5, NO induces potentiation when paired with a weak tetanus $(50 \mathrm{~Hz})$, but not when it is applied in the absence of presynaptic activity (Zhou et al 1993). One caveat regarding this study concerns the relatively high frequency of presynaptic stimulation required to elicit the NO-induced potentiation; in theory, frequencies as low as $1 \mathrm{~Hz}$ should be sufficient to produce potentiation, given that this frequency of presynaptic stimulation can induce LTP when paired with postsynaptic depolarization. Nonetheless, the observed activity-dependence of the NO-induced potentiation is noteworthy, since it may provide an explanation for how NO can mediate the input-specific nature of LTP: only those synapses that are active during LTP induction become potentiated (Barrionuevo \& Brown 1983).

The existence of a diffusible retrograde signal in LTP raises interesting possibilities regarding the specific synapses that will be influenced by its generation. In the absence of a precise targeting mechanism or an extremely efficient breakdown pathway, it is possible that a diffusible signal, such as NO, will interact with nearby synapses that have not participated directly in its production, resulting in a non-Hebbian heterosynaptic potentiation. Indeed, Bonhoeffer and colleagues have observed this type of potentiation in cultured hippocampal slices (Bonhoeffer et al 1989) and visual cortex slices (Kossel et al 1990). In these studies, pairing postsynaptic depolarization of an individual neuron with low-frequency stimulation resulted in a decrease in spike latency in the paired cell as well as a nearby cell. We (Schuman \& Madison 199lb, 1993) have also observed that in acute hippocampal slices, LTP induced by pairing in one CA1 pyramidal can spread to nearby $(\sim 100$ $\mu \mathrm{m})$, but not spatially remote $(>500 \mu \mathrm{m})$ synapses. These results are consistent with the postsynaptic generation of a diffusible factor, such as NO, that spreads to influence nearby synapses.

How does NO bring about the increase in synaptic strength that underlies LTP? An early study suggested that NO may activate a guanylyl cyclase, since membrane permeant analogues of cGMP (coapplied with an NOS inhibitor) partially reversed the inhibition of LTP normally observed with NOS inhibitors (Haley et al 1992). Sweatt and colleagues have also observed that tetanic stimulation results in large rises in cGMP that are blocked by NOS inhibitors (Chetkovich et al 1993). However, if guanylyl cyclase is the target of NO, then application of membrane permeant analogues of cGMP in 
conjunction with low-frequency presynaptic stimulation should be sufficient to potentiate synaptic transmission. This is not what has been experimentally observed (Schuman et al 1992). Under most stimulation parameters, extracellular application of cGMP analogues has no effect on baseline levels of synaptic transmission (Haley et al 1992). High-frequency stimulation delivered in the presence of cGMP analogues (and an NMDA receptor antagonist) usually results in a transient depression (Schuman et al 1992). Additionally, cGMP depresses a $\mathrm{Ca}^{2+}$ current in hippocampal neurons (Doerner \& Alger 1988); at first glance, this result is the opposite of what might be expected if cGMP were involved in increasing neurotransmitter release.

Another potentially interesting NO target in LTP may be a cytosolic ADP-ribosyltransferase (ADPRT) (Brune \& Lapetina 1989; Figure 2). An earlier study (Goh \& Pennefather 1989) showed that slices from rats pretreated with pertussis toxin, a bacterial ADP-ribosyltransferase, failed to exhibit LTP. Recent preliminary results suggest that LTP can be prevented by extracellular application of ADP-ribosyltransferase inhibitors (Schuman et al 1992). Postsynaptic injections of an ADPRT inhibitor did not prevent LTP, consistent with a presynaptic requirement for ADPRT activity. However, the link between NO production and ADP-ribosyltransferase activity in LTP is still untested. It will be interesting to see if NO-induced increases in synaptic strength are mediated by ADP-ribosyltransferase activity. Also, it remains to be determined whether LTP-inducing high-frequency stimulation results in the NO-dependent ADP-ribosylation of specific proteins.

In sum, evidence from several laboratories supports a role for $\mathrm{NO}$ as a signaling molecule in LTP. However, the involvement of NO in LTP is not without its mysteries or disputes. As mentioned previously, one caveat is the failure of most histological studies to detect NOS in the CA1 pyramidal cell region of the hippocampus. Recent studies, however, have identified NOSimmunopositive (Schweizer et al 1993) and NADPH diaphorase-staining (Wallace \& Fredens 1992) CAl pyramidal neurons. Also, since only one brain NOS isoform has been identified thus far (Bredt et al 1991c), it is possible that additional, as yet unidentified isoforms, not recognized by the available antibodies or oligonucleotides, may also be present in these neurons.

Another area of controversy concerns reports of NOS inhibitor-insensitive forms of LTP that occur under certain stimulation parameters (Gribkoff et al 1992. Chetkovich et al 1993) or at higher temperatures ( $\mathrm{Li}$ et al 1992, Chetkovich et al 1993). A recent study (Haley et al 1993) has examined both of these issues. These investigators found that at temperatures above $30^{\circ} \mathrm{C}$, NOS inhibitors block LTP induced by short $(2 \times 100 \mathrm{~Hz}$ for $0.25 \mathrm{~s})$, but not long $(2 \times 100 \mathrm{~Hz}$ for $0.5 \mathrm{~s})$ duration tetanic stimulation. These results suggest that at physiological temperatures stronger stimulation parameters may activate alternative biochemical pathways (see also Chetkovich et al 1993). 
A Annual Reviews

www.annualreviews.org/aronline

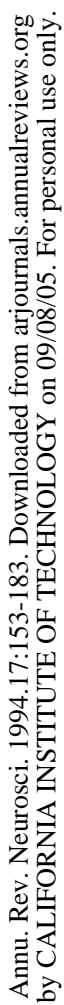
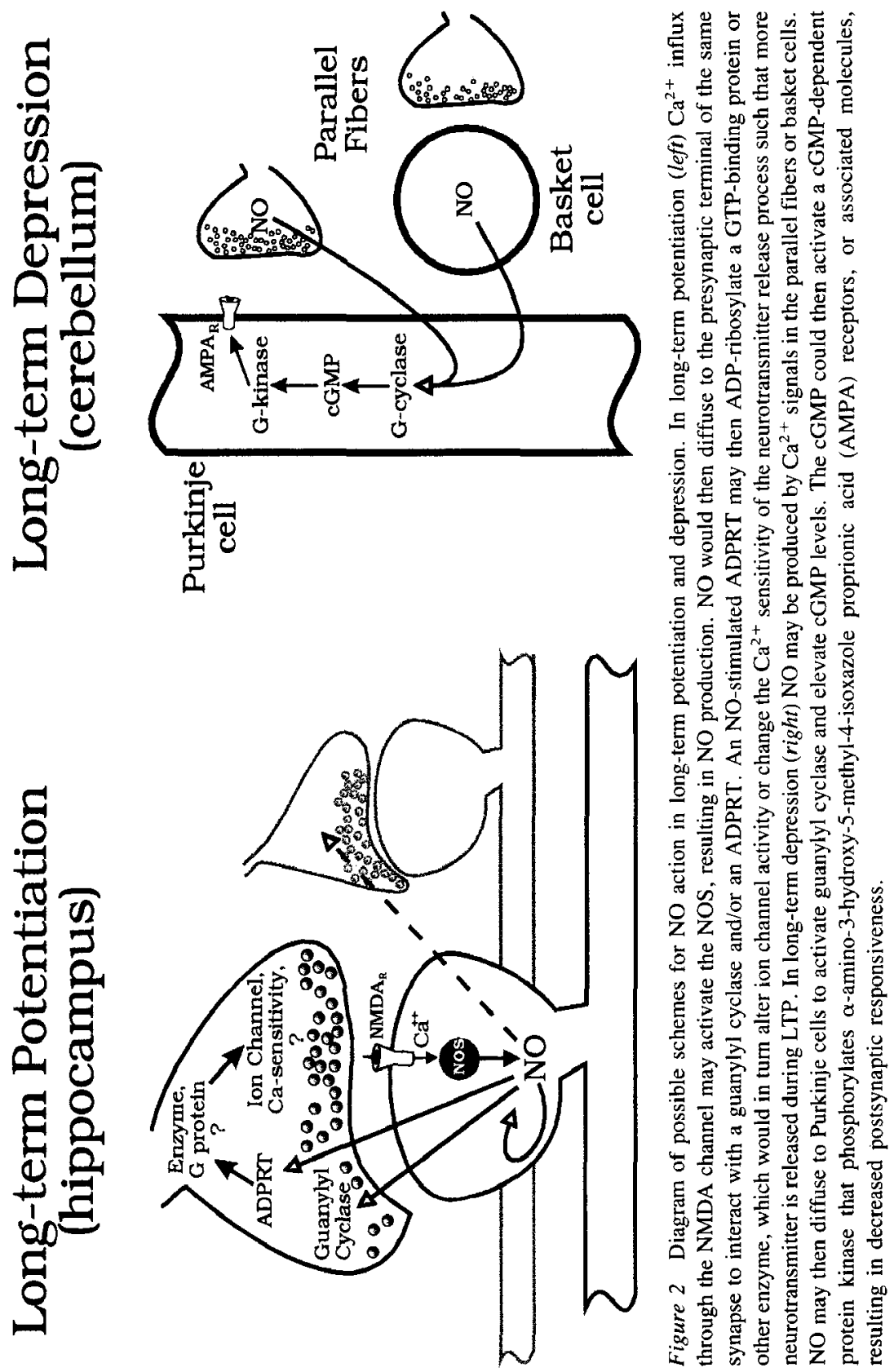

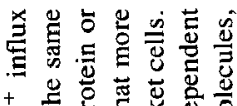

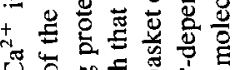
है. 巳 ฮี Ð

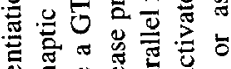

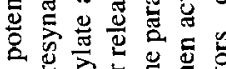

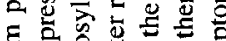

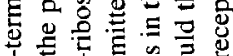

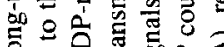

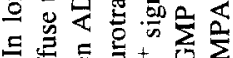

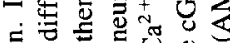

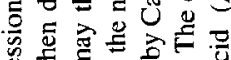

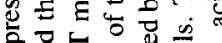

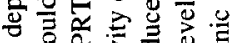

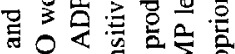

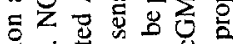
政 
NOS inhibitors have also been reported to block NMDA-mediated inhibition of LTP (Izumi et al 1992). Taken together, these findings suggest previously unappreciated complexities in the interactions between NO and the experimental paradigms used in LTP studies. Thus, in future endeavors, much more attention should be paid to the various LTP induction procedures and experimental conditions that are used in different labs. The breadth of biochemical pathways implicated in LTP is ever expanding. The task of future experiments will be to understand how various putative signaling pathways (e.g. arachidonic acid, carbon monoxide, and nitric oxide) may interact to ultimately orchestrate the observed increases in synaptic strength. In addition, the possibility that given biochemical pathways may be selectively invoked based on the stimulation parameters used to induce LTP (Gribkoff et al 1992, Haley et al 1993) or the preexisting history of the synapse (Izumi et al 1992, Larkman et al 1992) needs to be explored further.

\section{Long-Term Depression}

Certain patterns of neuronal activity can also lead to persistent decreases in synaptic strength, or long-term depression (LTD). Like LTP, LTD has been documented in many brain areas, including visual cortex, the hippocampus, and the cerebellum (Ito 1989). In the cerebellar cortex, the Purkinje cells possess two separate sets of excitatory synapses, one from the parallel fibers (granule cells axons) and one from the climbing fibers (inferior olive axons). Both the parallel fiber and the climbing fiber synapses use glutamate as a neurotransmitter. Conjunctive stimulation $(1-4 \mathrm{~Hz}$, for $25 \mathrm{~s}$ to $10 \mathrm{~min})$ of the parallel fibers and the climbing fibers produces a long-lasting depression of synaptic transmission at the synapses between the parallel fibers and Purkinje cells. The observed decrease in synaptic strength results from a reduction in the sensitivity of postsynaptic AMPA receptors (Ito et al 1982, Crepel \& Krupa 1988, Hirano 1991, Linden et al 1991).

Studies aimed at elucidating the molecular mechanisms that underlie LTD have outlined a series of events that includes glutamate binding to postsynaptic receptors, rises in intracellular $\mathrm{Ca}^{2+}$, and activation of protein kinase(s). Glutamate released from climbing fibers is thought to activate primarily the AMPA class of receptor. Because each climbing fiber possesses multiple synapses with each Purkinje cell, climbing fiber activity can potently depolarize Purkinje neurons, resulting in the activation of voltage-dependent $\mathrm{Ca}^{2+}$ channels and the influx of $\mathrm{Ca}^{2+}$. The glutamate released from parallel fibers has been proposed to activate both AMPA and metabotropic classes of glutamate receptors. Activation of both of these receptors is a necessary step in the induction of LTD, because antagonists to either class of receptor will block LTD (Linden et al 1991). Activation of the metabotropic receptor activates phospholipase $\mathrm{C}$, resulting in generation of diacylglycerol and an 


\section{SCHUMAN \& MADISON}

$\mathrm{IP}_{3}$-mediated rise in intracellular $\mathrm{Ca}^{2+}$. The $\mathrm{Ca}^{2+}$ signal (also derived from climbing fiber-mediated activation of voltage-sensitive $\mathrm{Ca}^{2+}$ channels), as well as the generation of diacylglycerol, serves to activate protein kinase C. PKC activity is required for LTD (Linden \& Connor 1991), and LTD can be mimicked by the application of phorbol esters (Crepel \& Krupa 1988). In addition to PKC, activation of cGMP-dependent protein kinase has also been implicated in LTD, as discussed in further detail below. The activity of these protein kinases has then been proposed to bring about alterations in the sensitivity of AMPA-type glutamate receptors by directly phosphorylating channel subunits or associated molecules.

Where might NO fit into the induction cascade outlined above? The brain NO synthase that was originally purified from cerebellum (Bredt $\&$ Snyder 1990 ) is found in the granule cells as well as the inhibitory basket cells, but has not been detected in the Purkinje cells (Bredt et al 1991b). Thus, the $\mathrm{Ca}^{2+}$ signal in Purkinje cells that is required for LTD most likely does not function as an activator of NOS (unless an as yet unidentified isoform of NOS exists in Purkinje cells). However, NOS may be activated by an influx of $\mathrm{Ca}^{2+}$ in the granule cells or by granule cell-induced excitation of the basket cells (Figure 2). If NO plays a role in LTD, then guanylyl cyclase is a likely target, since cGMP concentrations are much higher in the cerebellum than in other brain areas. Immunohistochemical studies indicate that guanylyl cyclase (Nakane et al 1983) and cGMP-dependent protein kinase (Lohmann et al 1981) are present in Purkinje cell bodies, dendrites, and axons. In contrast, cGMP is found primarily in Bergmann fibers and cell bodies, and in astroglial cells in the granular layer and white matter, but appears to be absent from Purkinje cells (de Vente et al 1989). In addition, several different agonists, including glutamate and kainate, as well as the NO donor sodium nitroprusside, fail to elevate cGMP in Purkinje neurons (Garthwaite \& Garthwaite 1987). These findings may indicate that the guanylyl cyclase present in Purkinje cells is stimulated by an as yet unidentified signal transduction cascade.

Is there any direct evidence that NO participates in LTD? Crepel \& Jaillard (1990, Daniel et al 1993) demonstrated that extracellular application of the NOS inhibitor L-NMMA blocks LTD produced by pairing parallel fiber-mediated EPSPs with postsynaptic Purkinje cell $\mathrm{Ca}^{2+}$ spikes in cerebellar slices. However, LTD is not blocked when the NOS inhibitor is included in the whole-cell recording pipette, suggesting that NO production is not required in Purkinje cells (Daniel et al 1993). In contrast, inclusion of an NO donor in the Purkinje cell recording pipette resulted in a progressive decline in the amplitude of parallel fiber-mediated EPSPs (Daniel et al 1993). This NO-mediated decrease in the EPSP prevented the subsequent induction of LTD by pairing parallel fiber stimulation with $\mathrm{Ca}^{2+}$ spikes. LTD can be prevented by the extracellular application of methylene blue, which has been reported to 
inhibit guanylyl cyclase (Crepel \& Jaillard 1990). In addition, bath or intracellular application of 8-bromo-cGMP also depressed the Purkinje cell EPSP. These results are consistent with a role for NO in LTD in which NO is produced by parallel fiber stimulation and then diffuses into the Purkinje cells to activate guanylyl cyclase and depress the EPSP.

A role for NO has been explored in another LTD paradigm. Ito \& Karachot (1990) have documented a quisqualate (QA)-induced desensitization of Purkinje cell glutamate receptors in grease gap recordings from Purkinje cell axons in cerebellar slices (Ito \& Karachot 1989). QA is believed to induce the observed desensitization by acting upon two classes of glutamate receptors, both the ionotropic AMPA type and the metabotropic type. Application of AMPA alone does not induce the desensitization (presumably because it does not act at the metabotropic receptor), but the coapplication of AMPA and the NO donor sodium nitroprusside or a membrane permeant cGMP analogue will produce desensitization (Ito \& Karachot 1990). Also, prior incubation with either the NOS inhibitor L-NMMA or hemoglobin blocked the QA-induced desensitization of responses. These results can be contrasted to the findings of Linden \& Connor (1992), who showed that in cultured Purkinje neurons, $\mathrm{NO}$ is not important for the depression glutamate currents produced by conjoint depolarization and glutamate iontophoresis. The differences in these two findings may be accounted for by the different preparations (cerebellar slices vs cultured Purkinje neurons) or the different induction procedures (quisqualate applications vs glutamate iontophoresis coupled with depolarization) used.

Another study has shown that a correlate of LTD, the alteration of extracellular $\mathrm{K}^{+}$concentration $\left(\left[\mathrm{K}^{+}\right]_{0}\right)$, is also influenced in a manner consistent with a role for NO. When the parallel fibers are stimulated in the molecular layer of a cerebellar slice, an increase in $\left(\left[\mathrm{K}^{+}\right]_{0}\right)$ can be recorded with an ion-sensitive electrode (Shibuki \& Okada 1990). LTD, produced by conjunctive stimulation, is accompanied by a depression of the parallel fiber-elicited $\mathrm{K}^{+}$response (Shibuki \& Okada 1990). The conjunctive stimulation-induced decrease in $\left(\left[\mathrm{K}^{+}\right]_{0}\right)$ is blocked when cerebellar slices are bathed in the NOS inhibitor L-NMMA or hemoglobin (Shibuki \& Okada 1991). In addition, sodium nitroprusside or a cGMP analogue paired with parallel fiber stimulation significantly depressed the $\mathrm{K}^{+}$response. This study also showed that an NO-sensitive probe inserted in the molecular layer was able to detect increases in NO concentration following conjunctive stimulation.

Thus, evidence from several studies suggests that NO functions as a important signal in the cellular events that underlie LTD. How might NO be incorporated into the anatomical and cellular circuitry important for LTD? The most parsimonious transduction scheme would most likely begin with NO generation in the basket or granule cells, induced by parallel fiber 


\section{SCHUMAN \& MADISON}

stimulation (Figure 2). NO would then diffuse to Purkinje cells to activate guanylyl cyclase, increase cGMP levels, and potentially activate a cGMP-dependent protein kinase. A cGMP-dependent protein kinase is one kinase that has been proposed to mediate the decreased postsynaptic responsiveness by phosphorylating a postsynaptic AMPA receptor or associated molecule (Ito 1989). A caveat to the above sequence of events is that researchers have been unable to observe NO stimulation of Purkinje cell guanylyl cyclase (Garthwaite \& Garthwaite 1987). In addition, the molecular underpinnings of the proposed down-regulation of the AMPA channels need to be further explored. It will be interesting to see whether the particular AMPA receptor subunits expressed in Purkinje cells possess consensus sites for phosphorylation by cGMP protein kinase or PKC, and whether NO can stimulate the phosphorylation of the receptor subunits by either of these kinases.

\section{Animal Learning}

The involvement of NO in LTP and LTD has prompted several investigators to explore the role of $\mathrm{NO}$ in the acquisition and retention of learned behavioral tasks, such as the Morris Water Maze, a radial arm maze, classical conditioning of the eyeblink response, and passive avoidance learning. The Morris Water Maze (Morris 1984) is a spatial learning task that requires an animal to find a platform submerged in a pool of opaque water based on spatial cues provided by the surrounding environment. During training trials, animals are placed at random positions in the pool and the amount of time it takes them to find the submerged platform is measured (escape latency). Previous work has shown that the hippocampus (Morris et al 1990) and NMDA receptor activity (Morris et al 1986) are required for animals to learn this task. A recent study suggests that one target of the NMDA-mediated $\mathrm{Ca}^{2+}$ influx that is necessary for learning this spatial task may be a NOS. Rats that received systemic injections of an NOS inhibitor (L-NAME; $75 \mathrm{mg} / \mathrm{kg}$ ) prior to training had significantly longer escape latencies than control animals (Chapman et al 1992). The effect of the NOS inhibitor was abolished when L-arginine was coadministered. When NOS inhibitors were injected after animals learned the task, the animals retained their ability to navigate to the platform, implying that NOS activity is required during the acquisition but not the retention of the memory.

Bohme and colleagues (1993) have also implicated NO in another test of spatial learning, performance in a radial arm maze. In this task, rats were required to make one visit to each arm of an eight-arm radial maze, in order to obtain a food reward. An error was recorded when a rat entered a previously visited arm within a given training period. Vehicle-injected controls can successfully navigate $(<2$ errors/session) in the maze by the third day of training. Rats that received injections of the NOS inhibitor L-NARG (100 
$\mathrm{mg} / \mathrm{kg}$, i.p.) for four days preceding the initiation of the training mastered this task much more slowly than other animals. This study also showed that the same injection of L-NARG prevented LTP in hippocampal slices prepared ex vivo. Lower doses $(25 \mathrm{mg} / \mathrm{kg})$ that were ineffective in blocking LTP from ex vivo slices also did not impair maze learning.

Classical conditioning of eyeblink responses involves pairing a tone (conditioned stimulus) with an air puff to the eye (unconditioned stimulus), which normally elicits an eyeblink. After days of training, the tone alone will elicit an eyeblink (conditioned response). Lesion studies in rabbits indicate that the acquisition of this learned behavior requires the cerebellum (McCormick \& Thompson 1984). Given the marked presence of the NOS in cerebellar granule cells, NO seems at the outset to be a good candidate for a mediator of this type of learning. Indeed, the acquisition of this classically conditioned response was blocked in rabbits that received daily injections $(10 \mathrm{mg} / \mathrm{kg})$ of L-NAME prior to training (Chapman et al 1992). However, on subsequent days when the injections were switched to D-NAME, the animals showed normal acquisition of the conditioned response. Interestingly, animals that had received D-NAME injections learned successfully, and their retention of the conditioned response could not be attenuated by subsequent injections of L-NAME. One caveat to the above study concerns the inverse dose-response relationship observed: lower doses $(10 \mathrm{mg} / \mathrm{kg})$ of L-NAME were effective in preventing the conditioned response, whereas higher doses $(75 \mathrm{mg} / \mathrm{kg})$ were ineffective.

Two studies have examined the requirement for NOS activity in different passive avoidance learning tasks. In a chick one-trial passive avoidance paradigm, chicks that initially peck at a bead coated with a bitter substance subsequently avoid dry, uncoated beads. A previous study suggested that this type of learning has been shown to rely on activation of NMDA receptors (Burchuladze \& Rose 1990). Holscher \& Rose (1992) found that chicks that received i.p. injections of NARG prior to training exhibited an initial disgust avoidance of the bitter bead, but did not avoid the bead during the test phase. The initial display of avoidance towards the bitter bead suggests that the NARG injections do not block learning by simply altering taste perception. These investigators also noted a failure of NOS inhibitors to alter established memory. In contrast, in a one-trial shock avoidance learning task, NOS inhibitors appeared not to interfere with learning (Bohme et al 1993). In this study, rats that received NOS inhibitor injections $(100 \mathrm{mg} / \mathrm{kg})$ learned as rapidly as control animals to avoid a dark chamber where they had previously experienced an electric shock. Thus, a requirement for NO in passive avoidance learning appears to depend on the species or the particulars of the experimental protocol, which may include the sensory modalities utilized during the tasks. It may be the case that NO is important for learning tasks 
that involve olfactory systems, since NOS inhibitors have also been shown to be important for another form of olfactory memory (Bohme et al 1993).

Thus several studies suggest that NO may participate in the acquistion of learned behaviors. However, a general caveat that must be applied to these studies involves potential systemic effects of blocking NO production. Alterations in blood pressure could alter an animal's ability to learn for a variety of reasons including alterations in motivation or activation of compensatory physiological systems that oppose learning. In addition, with the modes of inhibitor administration used in these studies (systemic or intaperitoneal injections) it is impossible to ascertain the site, neural or peripheral, where the inhibitor is action. A more informative approach might involve direct injections of NOS inhibitors into brain structures previously implicated in the behavioral changes. Nonetheless, keeping the above considerations in mind, these studies make a promising start toward the elucidation of how NO may modulate complex behavioral phenomena like learning and memory.

\section{PERSPECTIVES}

We have summarized data that suggests that NO is an important signaling molecule in a variety of physiological and pathophysiological processes. The observation that neuronal NOS requires both $\mathrm{Ca}^{2+}$ and calmodulin for its activity raises the possibility that NO may function in many other systems where rises in intracellular $\mathrm{Ca}^{2+}$, particularly those contributed by NMDA receptors, are known to act as a triggering step. Thus, the examples of NO-induced modulation discussed in this review are, no doubt, just a beginning.

In the various behavioral and cellular models of plasticity where the role of NO has been explored, it appears that NO functions as an early signal, responsible for the acquisition of information rather than its maintenance or long-term storage. This idea is suggested by the demonstrations that NOS inhibitors are without effect when injected after animals have learned either the Morris Water Maze, classical conditioning of eyeblink responses, or a passive avoidance task. These observations nicely parallel the finding that NOS inhibitors applied after the induction of LTP do not affect the enhanced synaptic transmission. Thus, continuous production of NO does not appear to underlie the long-lasting phases of synaptic or behavioral plasticity. Indeed, short-lived production of NO is what might be expected, given what is known about the activity of constitutive NOSs. However, it remains to be determined whether the activity of constitutive NOSs can be modified to produce NO for longer durations. In addition, it will be interesting to see if inducible NOSs, which produce NO for prolonged periods of time, may also be present in the central nervous system (see Galea et al 1992). 
Although it has not been explored in much detail, a role for NO appears promising (Gally et al 1990, Montague et al 1991) in the development and the stabilization of synaptic connections. Both neuronal activity and bidirectional synaptic signaling have been proposed to underlie the remodeling and refinement of many developing synapses (Kandel \& O'Dell 1992, Goodman \& Shatz 1993). NO may be well-suited to mediate some of these functions, since it is diffusible and optimally positioned to detect neural activity by virtue of the $\mathrm{Ca}^{2+}$-dependence of the NOS. In addition, NOS has also been localized to neurons known to play an important role in development. For example, in the cortex, NOS is localized to a small population of interneurons that are dispersed through layers II-VI as well as in the subcortical white matter (Mizukawa et al 1988). These interneurons in the subcortical white matter are derived from the population of subplate neurons (Chun \& Shatz 1989), which are known to pioneer the development of cortical connections (Ghosh et al 1990).

The notion of diffusible gaseous messengers raises the problem of how signaling specificity can be achieved. As mentioned above, one way specificity can be accomplished is to require the messenger production to coincide with synaptic activity. Indeed, this is what has been observed experimentally in the case of NO-induced increases in synaptic strength in the hippocampus (Zhou et al 1993). This concept is also highlighted by a recent report demonstrating NO-induced enhancement of immediate early gene expression (Peunova \& Enikolopov 1993). These investigators observed that NO can substantially augment the $\mathrm{Ca}^{2+}$-induced increases in c-fos expression, although NO alone was without effect. The facilitatory effect of NO required strict temporal contiguity of the $\mathrm{Ca}^{2+}$ and $\mathrm{NO}$ signals, indicating that coincidence detection can occur at the level of transcriptional regulation. Similar mechanisms to confer specificity may be employed in other systems that utilize diffusible messengers. Achieving a molecular understanding of NO's interaction with synaptic activity is an important area of future investigation.

Finally, although this review has dealt exclusively with potential functions of NO, it appears that there may be other forms of small diffusible signaling molecules, including $\mathrm{CO}$ (Verma et al 1993) and OH (Zoccarato et al 1989). The diffusibility of these messengers allows for coordinated molecular communication between ensembles of neurons, a feature not provided by conventional neurotransmitters. In addition, the extent and duration of each messenger's influence can be controlled by the different half-lives of the molecules as well as different diffusion constants. In future studies it will be interesting to see how the enzymatic pathways that make these new messenger molecules can be regulated and how these signals may ultimately interact to modulate the activity of synapses. 


\section{Literature Cited}

Aizenman E, Lipton SA, Loring RH. 1989. Selective modulation of NMDA responses by reduction and oxidation. Neuron 2:125763

Aizenman E, Hartnett KA, Reynolds IJ. 1990. Oxygen free radicals regulate NMDA receptor function via a redox modulatory site. Neuron 5:841-46

Amold WP, Mittal CK, Katsuki S, Murad F. 1977. Nitric oxide activates guanylate cyclase and increases guanosine $3^{\prime}: 5^{\prime}$-cyclic monophosphate levels in various tissue preparations. Proc. Natl. Acad. Sci. USA 74: 3203-7

Ascher P, Nowak L. 1988. The role of divalent cations in the N-methyl-D-aspartate responses of mouse central neurones in culture. J. Physiol. (London) 399:247-66

Barrionuevo G, Brown TH. 1983. Associative long-term potentiation in hippocampal slices. Proc. Natl. Acad. Sci. USA 80:734751

Beal MF, Kowall NW, Ellison DW, et al. 1986. Replication of the neurochemical characteristics of Huntington's disease by quinolinic acid. Nature 321:168-71

Beckman JS, Beckman TW, Chen J, et al. 1990. Apparent hydroxyl radical production by peroxynitrite: implications for endothelial injury from nitric oxide and superoxide. Proc. Natl. Acad. Sci. USA 87:1620-24

Bekkers JM, Stevens CF. 1990. Presynaptic mechanism for long-term potentiation in the hippocampus. Nature 346:724-29

Bohme GA, Bon C, Lemaire M, et al. 1993. Altered synaptic plasticity and memory formation in nitric oxide inhibitor treated rats. Proc. Natl. Acad. Sci. USA In press

Bohme GA, Bon C, Stutzmann JM, et al. 1991. Possible involvement of nitric oxide in longterm potentiation. Eur. J. Pharmacol. 199: 379-81

Bon C, Bohme GA, Doble A, et al. 1992. A role for nitric oxide in long-term potentiation. Eur. J. Neurosci. 4:420-24

Bonhoeffer T, Staiger V, Aertsen A. 1989. Synaptic plasticity in the rat hippocampal slice cultures: local "Hebbian" conjunction or pre- and postsynaptic stimulation leads to distributed synaptic enhancement. Proc. Natl. Acad. Sci. USA 86:8113-17

Bredt DS, Ferris CD, Snyder SH. 1992. Nitric oxide synthase regulatory sites: phosphorylation by cyclic AMP dependent protein kinase, protein kinase $\mathrm{C}$, calcium/calmodulin protein kinase; identification of flavin and calmodulin binding sites. J. Biol. Chem. 267:10976-81

Bredt DS, Glatt CE, Hwang PM, et al. 199lb. Nitric oxide synthase protein and mRNA are discretely localized in neuronal populations of mammalian central nervous system together with NADPH diaphorase. Neuron 7:615-24

Bredt DS, Hwang PH, Glatt C, et al. 1991c. Cloned and expressed nitric oxide synthase structurally resembles cytochrome P-450 reductase. Nature 351:714-18

Bredt DS, Hwang PH, Snyder SH. 1990. Localization of nitric oxide synthase indicating a neural role for nitric oxide. Nature 347:768-70

Bredt DS, Snyder SH. 1990. Isolation of nitric oxide synthetase, a calmodulin-requiring enzyme. Proc. Natl. Acad. Sci. USA 87:68285

Brune B, Lapetina EG. 1989. Activation of a cytosolic ADP-ribosyltransferase by nitric oxide generating agents. J. Biol. Chem. 264:8455-58

Brune B, Lapetina EG. 1990. Properties of a novel nitric oxide-stimulated ADP-ribosyltransferase. Arch. Biochem. Biophys. 279: 286-90

Brune B, Lapetina EG. 1991. Phosphorylation of nitric oxide synthase by protein kinase $A$. Biochem. Biophys. Res. Commun. 181:92126

Brune B, Ullrich V. 1987. Inhibition of platelet aggregation by carbon monoxide is mediated by activation of guanylate cyclase. $\mathrm{Mol}$. Pharmacol. 32:497-504

Burchuladze R, Rose SPR. 1990. Memory formation in the chick depends on membrane bound protein kinase C. Brain Res. 535:13138

Chapman PF, Atkins CM, Allen MT, et al. 1992. Inhibition of nitric oxide synthesis impairs two different forms of learning. NeuroReport 3:567-70

Chetkovich DM, Klann E, Sweatt JD. 1993. Nitric oxide synthase-independent long-term potentiation in area CAl of hippocampus. NeuroReport 4:919-22

Chun JJM, Shatz CJ. 1989. The earliest generated neurons of the cat cerebral cortex: characterization by MAP2 and neurotransmitter immunohistochemistry during fetal life. J. Comp. Neurol. 282:555-69

Collingridge GL, Kehl SJ, McLennan H. 1983. Excitatory amino acids in synaptic transmission in the Schaffer collateral-commisural pathway of the rat hippocampus. J. Physiol. 334:33-46

Costa A, Trainer P, Besser M, Grossman A. 1993. Nitric oxide modulates the release of corticotropin-releasing hormone from rat hypothalamus in vitro. Brain Res. 605:187-92

Crepel F, Jaillard D. 1990. Protein kinases, nitric oxide, and long-term depression of 
synapses in the cerebellum. NeuroReport. 1:133-36

Crepel F, Krupa M. 1988. Activation of protein kinase $\mathrm{C}$ induces a long-term depression of glutamate sensitivity of cerebellar Purkinje cells. An in vitto study. Brain Res. 458:397401

Daniel H, Hemart N, Jaillard D, Crepel F. 1993. Long-term depression requires nitric oxide and guanosine $3^{\prime}: 5^{\prime}$ cyclic monophosphate production in cerebellar purkinje cells. Eur. J. Neurosci. 5:1079-82

Dawson TM, Bredt DS, Fotuhi M, et al. 1991a. Nitric oxide synthase and neuronal NADPH diaphorase are identical in brain and peripheral tissues. Proc. Natl. Acad. Sci. USA 88:7797-801

Dawson VL, Dawson TM, London ED, et al. $1991 \mathrm{~b}$. Nitric oxide mediates glutamate neurotoxicity in primary cortical culture. Proc. Natl. Acad. Sci. USA 88:6368-71

Demerle-Pallardy C, Lonchampt M-O, Chabrier P-E, Braquet P, 1991. Absence of implication of L-arginie/Nitric oxide pathway on neuronal cell injury induced by l-glutamate or hypoxia. Biochem. Biophys. Res. Commun. 181:456-64

Desai KM, Sessa WC, Vane JR. 1991. Involvement of nitric oxide in the reflex relaxation of the stomach to accomodate food or fluid. Nature 351:477-79

de Vente J, Bol JGJM, Steinbusch HWM. 1989. Localization of cGMP in the cerebellum of the adult rat: an immunohistochemical study. Brain Res. 504:332-37

Dimmeler S, Brune B. 1992. Characterization of a nitric oxide-catalyzed ADP-ribosylation of glyceraldehyde-3-phosphate dehydrogenase. Eur. J. Biochem. 210:305-10

Dimmeler S, Lottspeich F, Brune B. 1992. Nitric oxide causes ADP-ribosylation and inhibition of glyceraldehyde-3-phosphate dehydrogenase. J. Biol. Chem. 267:16771-74

Doerner D, Alger BE. 1988. Cyclic GMP depresses hippocampal $\mathrm{Ca}^{2+}$ current through a mechanism independent of cGMP-dependent protein kinase. Neuron 1:693-99

Drapier JC, Hibbs JB. 1986. Murine cytotoxic activated macrophages inhibit aconitase in tumor cells. Inhibition involves the iron-sulfer prosthetic group and is reversible. $J$. Clin. Invest. 78:790-97

Duman RS, Terwilliger RZ, Nestler EJ. 1991. Endogenous ADP-ribosylation in brain: initial characterization of substrate proteins. $J$. Neurochem. 57:2124-32

East SJ, Batchelor AM, Garthwaite J. 1991. Selective blockade of $\mathrm{N}$-methyl-D-asparate receptor function by the nitric oxide donor, nitroprusside. Eur. J. Pharmacol. 209:11921

Ehret-Hilberer S, Nullans G, Aunis D, Virmaux N. 1992. Mono ADP-ribosylation of transducin catalyzed by rod outer segment extract. FEBS Lett. 309:394-98

Ferrante RJ, Kowall NW, Richardson EP, et al. 1985. Selective sparing of a class of striatal neurons in Huntington's disease. Science 230:561-63

Forstermann U, Schmidt HHHW, Kohlhass KL, Murad F. 1992. Induced RAW 267.4 macrophages express soluble and particulate nitric oxide synthase: inhibition by transferring growth factor-beta. Eur. J. Pharmacol. 225:161-65

Forstermann U, Pollock JS, Schmidt HHHW, et al. 1991. Calmodulin-dependent endothelium-derived relaxing factor/nitric oxide synthase activity is present in the particulate and cytosolic fractions of bovine aortic endothelial cells. Proc. Natl. Acad. Sci. USA 88:1788-92

Foster TC, McNaughton BL. 1991. Long-term enhancement of $\mathrm{CA} 1$ synaptic transmission is due to increased quantal size, not quantal content. Hippocampus 1:79-91

Furchgott RF, Jothianandan D. 1991. Endothelium-dependent and independent vasodilation involving cGMP: relaxation induced by nitric oxide, carbon monoxide, and light. Blood Vessels 28:52-61

Furchgott RF, Zawadski JV. 1980. The obligatory role of endothelial cells in the relaxation of arterial smooth muscle by acetylcholine. Nature 288:373-76

Galea E, Feinstein DL, Reis DJ. 1992. Induction of calcium-independent nitric oxide synthase in primary rat glial cultures. Proc, Natl. Acad. Sci. USA 89:10945-49

Gally JA, Montague PR, Reeke GN, Edelman GM. 1990. The NO hypothesis: possible effects of a short-lived, rapidly diffusible signal in the development and function of the nervous system. Proc. Natl. Acad. Sci. USA 87:3547-51

Garthwaite J, Charles SL, Chess-Williams R. 1988. Endothelium-derived relaxing factor release on activation of NMDA receptors suggests role as intracellular messenger in the brain. Nature 336:385-88

Garthwaite J, Garthwaite G. 1987. Cellular origins of cGMP responses to excitatory amino acid receptor agonists in rat cerebellum in vitro. J. Neurochem. 48:29-39

Geller DA, Lowenstein CJ, Shapiro RA, et al. 1993. Molecular cloning and expression of inducible nitric oxide synthase from human hepatocytes. Proc. Natl. Acad. Sci. USA 90:3491-95

Ghosh A, Antonini A, McConnell SK, Shatz CJ. 1990. Requirement for subplate neurons in the formation of thalamocortical connections. Nature $347: 179-81$

Goh JW, Pennefather PS. 1989. A pertussis toxin-sensitive $G$ protein in hippocampal long-term potentiation. Science 244:980-83 
Goodman CS, Shatz CJ. 1993. Developmental mechanisms that generate precise patterns of neuronal connectivity. Neuron 10:77-98

Granger DL, Taintor RR, Cook JL, Hibbs JB. 1980. Injury of neoplastic cells by murine macrophages leads to inhibition of mitochondrial respiration. J. Clin. Invest. 65:357-60

Gribkoff VK, Lum-Ragan JT. 1992. Evidence for nitric oxide synthase inhibitor-sensitive and insensitive hippocampal synaptic potentiation $J$. Neurophysiol. 68:639-42

Griffith TM, Edwards DH, Newby AC, et al. 1986. Production of endothelium-derived relaxant factor is dependent on oxidative phosphorylation and extracellular calcium. Cardiovasc. Res. 20:7-12

Haley JE, Wilcox GL, Chapman PF. 1992. The role of nitric oxide in long-term potentiation. Neuron 8:211-16

Haley JE, Malen PL, Chapman PF. 1993. Nitric oxide synthase inhibitors block LTP induced by weak, but not strong, tetanic stimulation at physiological brain temperatures in rat hippocampal slices. Neurosci. Lett. In press

Hanbauer I, Wink D, Osawa Y, et al. 1992. Role of nitric oxide in NMDA-evoked release from $\left[{ }^{3} \mathrm{H}\right]$-dopamine striatal slices. NeuroReport 3:409-12

Hibbs JB, Vavrin Z, Taintor RR. 1987. L-arginine is required for expression of the activated macrophage effector mechanism causing selective metabolic inhibition in target cells. J. Immunol. 138:550-56

Hibbs JB, Taintor RR, Vavrin Z, Rachlin EM. 1988. Nitric oxide: a cytotoxic activated macrophage effector molecule. Biochem. Biophys. Res. Commun. 157:87-94

Hiki K, Hattori R, Kawai C, Yui Y. 1992. Purification of insoluble nitric oxide synthase from rat cerebellum. J. Biochem. 111: $556-58$

Hirano T. 1991. Differential pre- and postsynaptic mechanisms for synaptic potentiation and depression between a granule cell and a Purkinje cell in rat cerebellar culture. Synapse $7: 321-23$

Holscher C, Rose SPR. 1992. An inhibitor of nitric oxide synthesis prevents memory formation in the chick. Neurosci. Lett. 145: 165-67

Hope BT, Michael GJ, Knigge KM, Vincent SR. 1991. Neuronal NADPH diaphorase is a nitric oxide synthase. Proc. Natl. Acad. Sci. USA 88:2811-14

Hoyt KR, Tang L-H, Aizenman E, Reynolds IJ. 1992. Nitric oxide modulates NMDA-induced increases in intracellular $\mathrm{Ca}^{2+}$ in cultured rat forebrain neurons. Brain Res. 592: $310-16$

Hyman BT, Marzloff $\mathbf{K}$, Wenniger $\mathbf{J}$, et al. 1992. Relative spanng of nitric oxide syn- thase-containing neurons in the hippocampal formation in Alzheimer's disease. Ann. Neurol. $32: 818-20$

Ignarro LJ, Buga GM, Wood KS, et al. 1987. Endothelium-derived relaxing factor produced and released from artery and vein is nitric oxide. Proc. Natl. Acad. Sci. USA 84:9265-69

Ito M. 1989. Long-term depression. Annu. Rev. Neurosci. 12:85-102

Ito M, Karachot L. 1989. Long-term desensitization of quisqualate-specific glutamate receptors in Purkinje cells investigated with wedge recordings from rat cerebellar slices. Neurosci. Res. 458:397-401

Ito M, Karachot L. 1990. Messengers mediating long-term desensitization in cerebellar Purkinje cells. NeuroReport 1:129-32

Ito M, Sakurai M, Tongroach P. 1982. Climbing fiber induced depression of both mossy fibre responsiveness and glutamate sensitivity of cerebellar Purkinje cells. J. Physiol. 324:113-24

Izumi Y, Clifford DB, Zorumski CF. 1992. Inhibition of long-term potentiation by NMDA-mediated nitric oxide release. Science 257:1273-76

Jahr CE, Stevens CF. 1987. Glutamate activates multiple single channel conductances in hippocampal neurones. Nature 325:52225

Janssens SP, Shimouchi A, Quertermous T, et al. 1992. Cloning and expression of a cDNA encoding human endothelium-derived relaxing factor/nitric oxide synthase. J. Biol. Chem. 267:14519-22

Kandel ER, O'Dell TJ. 1992. Are adult learning mechanisms also used for development? Science 258:243-45

Kaplan JM, Mardon G, Bishop JM, Varmus HE. 1988. The first seven amino acids encoded by the $\mathrm{v}$-src oncogene act as a myristylation signal: lysine 7 is a critical determinant. Mol. Cell. Biol. 8:2435-41

Kawano H, Daikoku S, Shibasaki T. 1988. CRF-containing neuron systems in the rat hypothalamus: retrograde tracing and immunohistochemical studies. J. Comp. Neurol. 272:260-68

Kiedrowski L, Costa E, Wroblewski JT. 1992. Sodium nitroprusside inhibits N-methyl-Daspartate-evoked calcium influx via a nitric oxide- and cGMP independent mechanism. Mol. Pharmacol. 41:779-84

Kiedrowski L, Manev H, Costa E, Wroblewski JT. 1991. Inhibition of glutamate-induced cell death by sodium nitroprusside is not mediated by nitric oxide. Neuropharmacology 30:1241-43

Knowles RG, Palacios M, Palmer RMG, Moncada S. 1989. Formation of nitric oxide from L-arginine in the central nervous system: a transduction mechanism for stimula- 
tion of soluble guanylate cyclase, Proc. Natl. Acad. Sci. USA 86:5159-62

Koh J-Y, Peters S, Choi DW. 1986. Neurons containing NADPH-diaphorase are selectively resistant to quinolate toxicity. Science 234:73-76

Kossel A, Bonhoeffer T, Bolz J. 1990. NonHebbian synapses in rat visual cortex. NeuroReport 1:115-18

Kots AY, Skurat AV, Sergienko EA, et al. 1992. Nitroprusside stimulates the cysteine-specific mono(ADP-ribosylation) of glyceraldehyde-3-phosphate dehydrogenase from human erythrocytes. FEBS Lett. 300:9-12

Kullmann DM, Nicoll RA. 1992. Long-term potentiation is associated with increases in quantal content and quantal amplitude. $\mathrm{Na}$ ture 357:240-44

Lamas S, Marsden PA, Li GK, et al. 1992. Endothelial nitric oxide synthase: molecular cloning and characterization of a distinct constitutive enzyme isoform. Proc. Natl. Acad. Sci. USA 89:6348-52

Larkman A, Hannay T, Stratford K, Jack J. 1992. Presynaptic release probability influences the locus of long-term potentiation. Nature 360:70-73

Lazarewicz JW, Wroblewski JT, Palmer ME, Costa E. 1989. Reduction of disulfide bonds activates NMDA-sensitive glutamate receptors in primary cultures of cerebellar granule cells. Neurosci. Res Commun. 4:91-97

Lei SZ, Pan Z.H, Aggarwal SK, et al. 1992. Effect of nitric oxide production on the redox modulatory site of the NMDA receptorchannel complex. Neuron 8:1087-99

Lemer-Natoli $M$, Rondouin $G$, deBock $F$, Bockaert J. 1992. Chronic NO synthase inhibition fails to protect hippocampal neurones against NMDA toxicity. NeuroReport 3:1109-12

Li YG, Errington ML, Williams JH, Bliss TVP. 1992. Temperature-dependent block of LTP by the NO synthase inhibitor LNARG. Soc. Neurosci. Abstr. 18:342

Linden DJ, Connor JA. 1991. Participation of postsynaptic PKC in cerebellar long-term depression in culture. Science 254:1656-59

Linden DJ, Connor JA. 1992. Long-term depression of glutamate currents in cultured cerebellar purkinje neurons does not require nitric oxide signalling. Eur. J. Neurosci. 4:10-15

Linden DJ, Dickinson MH, Smeyne M, Connor JA. 1991. A long-term depression of AMPA currents in cultured cerebellar Purkinje neurons. Neuron 7:81-89

Lohmann SM, Walter U, Miller PE, et al. 1981. Immunohistochemical localization of cyclic GMP-dependent protein kinase in mammaliam brain. Proc. Natl. Acad. Sci. USA 78:653-57
Lonart G, Wang J, Johnson KM. 1992. Nitric oxide induces neurotransmitter release from hippocampal slices. Eur. J. Pharmacol. 220: $271-72$

Lovinger DM, Wong KL, Murakami K, Routtenberg A. 1987. Protein kinase C inhibitors eliminate long-term potentiation. Brain Res, 436:177-83

Lowenstein CJ, Glatt CS, Bredt DS, Snyder SH. 1992. Cloned and expressed macrophage nitric oxide synthase contrasts with the brain enzyme. Proc. Natl, Acad, Sci. USA 89:6711-15

Lustig HS, von Brauchitsch KL, Chan J, Greenberg DA. 1992. cGMP modulators and excitotoxic injury in cerebral cortical cultures. Brain Res. 577:343-46

Lynch G, Baudry M. 1984. The biochemistry of memory: a new and specific hypothesis. Science 224:1057-63

Lynch G, Larson J, Kelso S, et al, 1983. Intracellular injections of EGTA block induction of hippocampal long-term potentiation. Nature 305:719-21

Lyons CR, Orloff GJ, Cunningham JM. 1992. Molecular cloning and functional expression of an inducible nitric oxide synthase from a murine macrophage cell line. J. Biol. Chem. 267:6370-74

MacDermott AB, Mayer ML, Westbrook GL, et al. 1986. NMDA-receptor activation increases cytoplasmic calcium concentration in cultured spinal cord neurones. Nature 321:519-22

Madison DV, Malenka RC, Nicoll RA. 1991. Mechanisms underlying long-term potentiation of synaptic transmission. Annu. Rev. Neurosci. 14:379-97

Malenka RC, Kauer JA, Perkel DJ, et al. 1989. An essential role for postsynaptic calmodulin and protein kinase activity in long-term potentiation. Nature 340:554-57

Malenka RC, Kauer JA, Zuker RJ, Nicoll RA. 1988. Postsynaptic calcium is sufficient for potentiation of hippocampal synaptic transmission. Science 242:81-84

Malgaroli A, Tsien RW. 1992. Glutamate-induced long-term potentiation of the frequency of miniature synaptic currents in cultured hippocampal neurones. Nature 357 : 134-39

Malinow R. 1991. Transmission between pairs of hippocampal slice neurons: quantal levels, oscillations and LTP. Science 252:722-24

Malinow R, Madison DV, Tsien RW. 1988. Persistent protein kinase activity underlies long-term potentiation. Nature 335:820-24

Malinow R, Miller JP. 1986. Postsynaptic hyperpolarization during conditioning reversibly blocks induction of long-term potentiation. Nature 320:529-30

Malinow R, Schulman R, Tsien RW. 1989. Inhibition of postsynaptic PKC or CAMKII 
blocks induction but not expression of LTP. Science 245:862-66

Malinow R, Tsien RW. 1990. Presynaptic enhancement shown by whole-cell recordings of long-term potentiation in hippocampal slices. Nature 346:177-80

Manabe T, Renner P, Nicoll RA. 1992. Postsynaptic contribution to long-term potentiation revealed by the analysis of miniature synaptic currents. Nature 355:50-55

Manzoni O, Prezeau L, Deshager S, et al. 1992a. Sodium nitroprusside blocks NMDA receptors via formation of ferrocyanide ions. NeuroReport 3:77-80

Manzoni O, Prezeau L, Marin P, et al. 1992b. Nitric oxide-induced blockade of NMDA receptors. Neuron 8:653-62

Marletta MA. 1989. Nitric oxide: biosynthesis and biological significance. Trends Biol. Sci. $14: 488-92$

Marsden PA, Schappert KT, Chen HS, et al. 1992. Molecular cloning and characterization of human endothelial nitric oxide synthase. FEBS Lett. 307:287-93

Mayer ML, Westbrook GL. 1987. Permeation and block of N-methyl-D-aspartic acid receptor channels by divalent cations in mouse central neurones. J. Physiol. 394: 501-28

McCormick DA, Thompson RF. 1984. Cerebellum: essential involvement in the classically conditioned eyelid response. Science 223:296-99

Miki N, Kawabe Y, Kuriyama K. 1977. Activation of cerebral guanylate cyclase by nitric oxide. Biochem. Biophys. Res. Commun. 75:851-56

Molina y Vedia L, McDonald B, Reep B, et al. 1992. Nitric oxide-induced S-nitrosylation of glyceraldehyde-3-phosphate dehydrogenase inhibits enzyme activity and increase endogenous ADP-ribosylation. J. Biol. Chem. 267:24929-32

Mizukawa K, Vincent SR, McGeer PL, McGeer EG. 1988. Ultrastructure of reduced nicotinamide dinucleotide phosphate (NADPH) diaphorase- positive neurons in the cat cerebral cortex, amygdala and caudate putamen. Brain Res. 452:286-92

Montague PR, Gally JA, Edelman GM. 1991. Spatial signaling in the development and function of neural connections. Cereb. Cortex 1:199-220

Morris RGM. 1984. Development of a water maze procedure for studying spatial learning in the rat. J. Neurosci. Meth. 11:47-60

Morris RGM, Anderson E, Lynch GS, Baudry M. 1986. Selective impairment of learning and blockade of long-term potentiation by an $\mathrm{N}$-methyl-D-aspartate receptor antagonist AP5. Nature 319:774-76

Morris RGM, Schenk F, Tweedie F, Jarrard L. 1990. Ibotenate lesions of the hippocampus and/or subiculum: dissociating components of allocentric spatial learning. Eur. J. Neurosci. 2:1016-28

Murad F, Mittal CK, Arnold WP, et al. 1978. Guanylate cyclase: activation by azide, nitro compounds, nitric oxide, and hydroxyl radical and inhibition by hemoglobin and myoglobin. Adv. Cyclic Nucl. Res. 9:145-58

Nakaki T, Nakayama M, Kato R. 1990. Inhibition by nitric oxide and nitric oxide-producing vasodilators of DNA synthesis in vascular smooth muscle cells. Eur. J. Pharmacol. 189:347-53

Nakane M, Ichikawa M, Deguchi T. 1983. Light and electron microscopic demonstration of guanylate cyclase in rat brain. Brain Res. 273:9-15

Nakane M, Mitchell J, Forstermann U, Murad F. 1991. Phosphorylation by calcium-calmodulin-dependent protein kinase II and protein kinase $\mathrm{C}$ modulates the activity of nitric oxide synthase. Biochem. Biophys. Res. Commun. 180:1396-402

Nowak L, Bregestovski P, Ascher P, et al. 1984. Magnesium gates glutamate-activated channels in mouse central neurones. Nature 307:462-65

Nowicki JP, Duval D, Poignet H, Scatton B. 1991. Nitric oxide mediates neuronal death after focal cerebral ischemia in the mouse. Eur. J. Pharmacol. 204:339-40

O'Dell TJ, Hawkins RD, Kandel ER, Arancio O. 1991. Tests on the roles of two diffusible substances in LTP: evidence for nitric oxide as a possible early retrograde messenger. Proc. Natl. Acad. Sci. USA 88:11285-89

Palmer RMJ, Ferrige AG, Moncada S. 1987. Nitric oxide accounts for the biological activity of endothelium-derived relaxing factor. Nature 327:524-26

Pauwels P, Leysen JE. 1992. Blockade of nitric oxide formation does not prevent glutamateinduced neurotoxicity in neuronal cultures from rat hippocampus. Neurosci. Lett. 143: 27-30

Peunova N, Enikolopov G. 1993. Amplification of calcium-induced gene transcription by nitric oxide in neuronal cells. Nature. 364:450-53

Pollock JS, Förstermann U, Mitchell JA, Warner TA, Schmidt HHHW, et al. 1991. Purification and characterization of particulate endothelium-derived relaxing factor synthase from cultured and native bovine aortic endothelial cells. Proc. Natl. Acad. Sci. USA 88: $10480-84$

Pollock JS, Klinghofer V, Forstermann U, Murad F. 1992. Endothelial nitric oxide synthase is myristylated. FEBS Lett. 309: 402-4

Prast H, Phillipu A. 1992. Nitric oxide releases acetylcholine in the basal forebrain. Eur. J. Pharmacol. 216:139-40

Puttfarcken PS, Lyons WE, Coyle JT. 1992. 
Dissociation of nitric oxide generation and lainiate-mediated neuronal degeneration in primary cultures of rat cerebellar granule cells. Neuropharmacology 31:565-75

Rajfer J, Aronson WJ, Bush PA, et al. 1992. Nitric oxide as a mediator of the corpus cavernosum in response to nonadrenergic non cholinergic transmission. $N$. Engl. J. Med. 326:90-94

Rapoport RM, Draznin MB, Murad F. 1983. Endothelium-dependent relaxation in rat aorta may be mediated through cGMP-dependent phosphorylation. Nature 306:174 76

Rashatwar SS, Cornwell TL, Lincoln TM, 1987. Effects of 8-bromo-cGMP on $\mathrm{Ca}^{2+}$ levels in vascular smooth muscle cells: possible regulation of $\mathrm{Ca}^{2+}$-ATPase by cGMP. dependent protein kinase. Proc. Natl. Acad. Sci. USA 84:5685-89

Schmidt HHHW, Pollock JS, Nakane M, et al. 1992. $\mathrm{Ca}^{2+} /$ calmodulin-regulated nitric oxide synthases. Cell Calcium 13:427-34

Schuman EM, Madison DV. 1991a. A require ment for the intercellular messenger nitric oxide in long-term potentiation. Science 254: 1503-6

Schuman EM, Madison DV. 1991b. An inhibitor of nitric oxide synthase prevents longterm potentiation (LTP). Soc. Neurosci. Abstr. 17:2

Schuman EM, Madison DV. 1993. Long-term potentiation induced in a single CAl pyramidal neuron can enhance nearby, but not distant, synapses. Soc. Neurosci. Abstr. In press

Schuman EM, Meffert MK, Schulman H, Madison DV. 1992. A potential role for an ADP-ribosyltransferase in hippocampal long-term potentiation. Soc. Neurosci. Abstr. 18:761

Schweizer FE, Wendland B, Ryan TA, et al. 1993. Evidence for the presence of nitric oxide synthase in rat hippocampal pyramidal cells. Soc. Neurosci. Abstr. In press

Sessa WC, Harrison JK, Barber CM, et al. 1992. Molecular cloning and expression of a cDNA encoding endothelial cell nitric oxide synthase. J. Biol. Chem. 267:15274 76

Shibuki K, Okada D. 1990. Long-term synaptic changes in rat cerebellar slices reflected in extracellular K+ activity. Neurosci. Lett. 113:34-39

Shibuki K, Okada D. 1991. Endogenous nitric oxide release required for long-term synaptic depression in the cerebellum. Nature 349: 326-28

Silva AJ, Stevens CF, Tonegawa S, Wang Y. 1992. Deficient hippocampal long-term potentiation in $\alpha$-calcium-calmodulin kinase II mutant mice. Science 257:201-6

Southam E, Garthwaite J. 1991. Comparative effects of some nitric oxide donors on cyclic
GMP levels in rat cerebellar slices. Neurosci. Lett. 130:107-11

Stuehr DJ, Marletta MA. 1987. Induction of nitrite/nitrate synthesis in murine macrophages by $\mathrm{BCG}$ infection, lymphokines, or interferon $\gamma$.J. Immunol. 139:518-25

Tauck DL. 1992. Redox modulation of NMDA receptor-mediated synaptic activity in the hippocampus. NeuroReport 3:781-84

Ueda K, Hayaishi O. 1985. ADP-ribosylation. Annu. Rev. Biochem. 54:73-100

Valtschanoff JG, Weinberg RJ, Kharazia VN, et al. 1993. Neurons in the rat hippocampus that synthesize nitric oxide. J. Comp. Neurol. $330 ; 1-11$

Verma A, Hirsch DJ, Glatt CE, et al. 1993. Carbon monoxide: a putative neural messenger. Science 259:381-84

Vincent SR, Johansson O, Hokfelt $\mathrm{T}$, et al. 1983. NADPH-diaphorase: a selective histochemical marker for striatal neurons containing both somatostatin- and avian pancreatic polypeptide (APP)-like immunoreactivities. J. Comp. Neurol. 217:252-63

Wallace MN, Fredens K. 1992. Activated astrocytes of the mouse hippocampus contain high levels of NADPH-diaphorase. NeuroReport 3:953-56

Williams JH, Errington ML, Bliss TVP. 1989. Arachidonic acid induces a long-term activity-dependent enhancement of synaptic transmission in the hippocampus. Nature 341:739-42

Williams MB, Li X, Gu X, Jope RS. 1992. Modulation of endogenous ADP-ribosylation in rat brain. Brain Res. 592:49-56

Wolin MS, Wood KS, Ignarro LJ. 1982. Guanylate cyclase from bovine lung. A kinetic analysis of the regulation of unpurified soluble enzyme by protoporphyrin IX, heme, and nitrosyl-heme. J. Biol. Chem. 257: 11312-20

Xie Q, Cho HJ, Calayeay J, et al. 1992. Cloning and characterization of inducible nitric oxide synthase from mouse macro. phages. Science 256:225-28

Zhang J, Snyder SH. 1992. Nitric oxide stimulates auto-ADP-ribosylation of glyceraldehyde-3-phosphate dehydrogenase. Proc. Natl. Acad. Sci. USA 89:9382-85

Zhou M, Small SA, Kandel ER, Hawkins RD. 1993. Nitric oxide and carbon monoxide produce long-term enhancement of synaptic transmission in the hippocampus by an activity-dependent mechanism. Science 260: $1946-49$

Zhu XZ, Luo LG. 1992. Effect of nitroprusside (nitric oxide) on endogenous dopamine release from rat striatal slices. $J$. Neurochem. 59:932-35

Zoccarato F, Deana R, Cavallini L, Alexandre A. 1989. Generation of hydrogen peroxide by cerebral-cortex synaptosomes. Eur. J. Biochem. 180:473-78 


\footnotetext{
$\overline{\mathrm{R}} \quad$ Annual Review of Neurosci.
Volume 17, 1994
}

\section{CONTENTS}

Development of Motorneuronal Phenotype, Judith S. Eisen

Cloned Glutamate Receptors, Michael Hollmann and Stephen Heinemann

Hox Genes and Regionalization of the Nervous System, Roger Keynes and Robb Krumlauf

The Early Reactions of Non-Neuronal Cells to Brain Injury, Dennis $M . D$. Landis

Nitric Oxide and Synaptic Function, Erin $M$. Schuman and Daniel V. Madison

The Subplate, A Transient Neocortical Structure: Its Role in the Development of Connections Between Thalamus and Cortex, Karen L. Allendoerfer and Carla J. Shatz

Synaptic Vesicles ANd Exocytosis, R. Jahn and T. C. Südhof

The Epigenetics of Multiple Sclerosis: Clues to Etiology and a Rationale for Immune Theory, Lawrence Steinman, Ariel Miller, Claude C. A. Bernard, and Jorge R. Oksenberg

Neuronal Polarity, Ann Marie Craig and Gary Banker

Prion Diseases and Neurodegeneration, Stanley B. Prusiner and Stephen J. DeArmond

DENDRITIC SpINES: Cellular Specializations Imparting Both Stability and Flexibility to Synaptic Function, Kristen Harris and S. B. Kater

Determination of Neuronal Cell Fate: Lessons from the R7 Neuron of Drosophila, S. Lawrence Zipursky and Gerald Rubin

Molecular Basis for $\mathrm{CA}^{2+}$ Channel Diversity, $F$. Hofmann, M.Biel and V. Flockerzi 
vi Contents (Continued)

Specification of Neocortical Areas and Thalamocortical. Connections, Dennis D. M. O'Leary, Bradley L. Schlaggar and Rebecca Tuttle

Direct G Protein Activation of Ion Channels?, David E. Clapham

The Anatomy and Physiology of Primate Neurons That Control Rapid Eye Movements, A. K. Moschovakis and S. M. Highstein

Normal and Abnormal Biology of the $\beta$-Amyloid Precursor Protein, Dennis J. Selkoe

Organization of Memory Traces in the Mammalian Brain, Richard F. Thompson and David J. Krupa

The Protein Kinase C Family for Neuronal Signaling, Chikako Tanaka and Yasutomi Nishizuka

GABA $_{\mathrm{A}}$ ReCEPTOR CHANnels, Robert L. Macdonald and Richard W. Olsen

INDEXES

Subject Index

Cumulative Index of Contributing Authors, Volumes 11-17

Cumulative Index of Chapter Titles, Volumes 11-17 